\title{
A Retrospective Analysis of the Cartilage Kunitz Protease Inhibitory Proteins Identifies These as Members of the Inter- $\alpha$-Trypsin Inhibitor Superfamily with Potential Roles in the Protection of the Articulatory Surface
}

\author{
Susan M. Smith ${ }^{1}$ and James Melrose ${ }^{1,2,3,4, *}$ \\ 1 Raymond Purves Bone and Joint Research Laboratory, Kolling Institute, Northern Sydney Local Health \\ District, St. Leonards, NSW 2065, Australia; Susan.smith@sydney.edu.au \\ 2 Graduate School of Biomedical Engineering, University of New South Wales, Sydney, NSW 2052, Australia \\ 3 Sydney Medical School, Northern, The University of Sydney, Royal North Shore Hospital, \\ St. Leonards, NSW 2065, Australia \\ 4 Faculty of Medicine and Health, University of Sydney, Royal North Shore Hospital, \\ St. Leonards, NSW 2065, Australia \\ * Correspondence: james.melrose@sydney.edu.au; Tel.: +61-299-264-806; Fax.: +61-299-265-266
}

Received: 29 December 2018; Accepted: 21 January 2019; Published: 24 January 2019

\begin{abstract}
Aim: The aim of this study was to assess if the ovine articular cartilage serine proteinase inhibitors (SPIs) were related to the Kunitz inter- $\alpha$-trypsin inhibitor (ITI) family. Methods: Ovine articular cartilage was finely diced and extracted in $6 \mathrm{M}$ urea and SPIs isolated by sequential anion exchange, HA affinity and Sephadex G100 gel permeation chromatography. Selected samples were also subjected to chymotrypsin and concanavalin-A affinity chromatography. Eluant fractions from these isolation steps were monitored for protein and trypsin inhibitory activity. Inhibitory fractions were assessed by affinity blotting using biotinylated trypsin to detect SPIs and by Western blotting using antibodies to $\alpha 1$-microglobulin, bikunin, TSG-6 and 2-B-6 (+) CS epitope generated by chondroitinase-ABC digestion. Results: 2-B-6 (+) positive 250, 220,120, 58 and 36 kDa SPIs were detected. The $58 \mathrm{kDa}$ SPI contained $\alpha 1$-microglobulin, bikunin and chondroitin-4-sulfate stub epitope consistent with an identity of $\alpha 1$-microglobulin-bikunin (AMBP) precursor and was also isolated by concanavalin-A lectin affinity chromatography indicating it had $\mathrm{N}$-glycosylation. Kunitz protease inhibitor (KPI) species of 36, 26, 12 and $6 \mathrm{kDa}$ were autolytically generated by prolonged storage of the 120 and $58 \mathrm{kDa}$ SPIs; chymotrypsin affinity chromatography generated the $6 \mathrm{kDa}$ SPI. KPI domain 1 and 2 SPIs were separated by concanavalin lectin affinity chromatography, domain 1 displayed affinity for this lectin indicating it had $\mathrm{N}$-glycosylation. KPI 1 and 2 displayed potent inhibitory activity against trypsin, chymotrypsin, kallikrein, leucocyte elastase and cathepsin G. Localisation of versican, lubricin and hyaluronan (HA) in the surface regions of articular cartilage represented probable binding sites for the ITI serine proteinase inhibitors (SPIs) which may preserve articulatory properties and joint function. Discussion/Conclusions: The Kunitz SPI proteins synthesised by articular chondrocytes are members of the ITI superfamily. By analogy with other tissues in which these proteins occur we deduce that the cartilage Kunitz SPIs may be multifunctional proteins. Binding of the cartilage Kunitz SPIs to HA may protect this polymer from depolymerisation by free radical damage and may also protect other components in the cartilage surface from proteolytic degradation preserving joint function.
\end{abstract}

Keywords: $\quad$ serine proteinase inhibitor; Kunitz; bikunin; inter- $\alpha$-trypsin inhibitor; pre- $\alpha$-trypsin inhibitor 


\section{Introduction}

Inter- $\alpha$-trypsin inhibitor (ITI) was first discovered as a serum proteinase inhibitor by Steinbuch and Loeb in 1961 [1]. A series of studies subsequently demonstrated ITI in the sera of a number of animals including, bovine, cervine, equine, porcine, donkey, lapine, canine, rat and ovine sources and its susceptibility to limited proteolysis by a trypsin-like serine proteinase yielding a number of characteristic trypsin inhibitory species [2-5]. Further studies led to the identification of two Kunitz protease inhibitor domains in the ITI light chain which was subsequently named bikunin $[2,5]$. An additional related large ITI serum inhibitor of $120 \mathrm{kDa}$ was also identified, which could be cleaved by limited digestion with kallikrein into 100 and $35 \mathrm{kDa}$ fragments [6], this was named pre- $\alpha$-trypsin inhibitor (pre- $\alpha$-TI) [7]. Bikunin was subsequently shown to be a proteoglycan with the identification of a chondroitin sulfate (CS) side chain [8-12]. Bikunin is unique among the proteoglycans in that its CS chain acts as an internal linkage module for the attachment of a number of heavy chain proteins in ITI $[5,13]$. The mature ITI/pre- $\alpha$-TI molecule contains three heavy and one light chain in a molecule of 120-250 kDa in size synthesised in the liver and secreted into serum [5]. Further studies have demonstrated up to six heavy chains attached to ITI in a number of tissues $[14,15]$ and truncated heavy chains in fibrillated regions of osteoarthritic (OA) human articular cartilage (AC) [16].

ITI has interactive properties with hyaluronan (HA) which are promoted by the small glycoprotein TSG-6 particularly under inflammatory conditions. This may protect the HA through transfer of ITI heavy chains which cross-link the HA stabilising and countering its de-polymerisation by free radicals released by inflammatory cells during OA and rheumatoid arthritis (RA) [17]. The ITI Kunitz serine protease inhibitor (SPI) proteins detected in AC are biosynthetic products of the chondrocytes [18]. Previous studies with isolated chondrocytes and intervertebral disc (IVD) cells have demonstrated the synthesis of 6, 12, 26, 36, and $58 \mathrm{kDa}$ SPI species in alginate bead culture [18,19]. How intact ITI is degraded into its Kunitz SPI domains (KPIs) in AC has not been determined but by analogy to in vitro studies on serum ITI this is likely to involve a serine proteinase, chondrocytes synthesise a chymotrypsin-like serine protease which is a likely candidate [20]. Chymotrypsin affinity chromatography of cartilage SPI-120 and SPI- 58 converts these to 36, 26, 12 and 6 kDa KPI species confirming earlier ovine studies [18,21] similar KPIs have been generated from sheep serum ITI [22]. The ITI SPIs are normally identified using antibodies; however, this does not give any information on their biological status. In the course of our studies on the SPIs of AC and IVD we developed a sensitive Affinity blotting procedure using biotinylated trypsin (bT), which can be used alongside conventional antibody blots. This is a useful sensitive technique capable of detecting low ng-pg levels of SPI and also demonstrates the SPI is biologically active [21,23,24]. In the present study we have used both of these techniques which complement one another to demonstrate that many of the SPIs previously identified in AC and IVD are in fact members of the ITI superfamily [18,19,21,25-31].

Despite displaying potent protease inhibitory properties against a number of serine proteases including leucocyte elastase and cathepsin G, pancreatic trypsin and chymotrypsin, plasmin, kallikrein and some of the coagulation cascade proteinases the requirement for additional serine protease inhibitory activity in serum is questionable given that serum already contains $\alpha 1$-proteinase inhibitor, antithrombin-III, C1 esterase inhibitor, $\alpha 2$-antiplasmin, $\alpha 1$-antichymotrypsin, and $\alpha 2$-macroglobulin which display a broad inhibitory spectra and high capacity for protease inhibition. Thus, in some respects ITI was a redundant SPI activity in serum. On-going studies on ITI have however now shown it has a diverse range of properties far and beyond that of protease inhibition [12,32-37]. ITI transports its heavy chains to HA, a process of trans-esterification catalysed by the enzyme TSG-6 [17,38]. This produces condensed HA deposits in certain tissues of functional significance, HA deposition around oocytes is essential for their protection from free radical damage and in their expansion to promote fertilisation [39,40], condensed HA is also found in the growth plate and appears important in the cartilage to bone transition in endochondral ossification [41]. The KPI domains of ITI also have intrinsic biological properties and convey anti-bacterial [42,43], anti-viral [44-47], anti-tumour [44,45], anti-inflammatory $[33,37,48,49]$, innate immunomodulatory properties in host-defense [50] and cell 
regulatory properties which promote wound repair [51]. KPI domain proteins are bi-functional in a number of marine, parasite, snake, scorpion and tick venom KPI proteins providing voltage-gated ion blocking properties as well as protease inhibition [52-58]. This provides clues as to the full functional capability of ITI in mammalian tissues. The present study isolated and characterised cartilage KPIs generated in-situ from a $\alpha 1$-microglobulin-bikunin precursor protein related to ITI and pre- $\alpha$-TI. These should not be confused with two additional 6 and $12 \mathrm{kDa}$ cationic SPIs found in human AC (secretory leucocyte proteinase inhibitor, SLPI; and elafin) which are also Kunitz domain SPIs but derived from different precursor proteins to the ITI SPIs $[43,51,59,60]$. Ovine AC also contains two homologues of SLPI and elafin (ovine SLPI and Trappin ovine molecule, TOM), which share moderate levels of sequence homology $(\sim 60 \%)$ [61-63].

\section{Results}

Anion exchange chromatography of the $6 \mathrm{M}$ urea extract of pooled ovine stifle joint cartilage resulted in $\sim 60 \%$ of the extracted protein unbound and bound SPI which was eluted at between 0.1 to $0.3 \mathrm{M} \mathrm{NaCl}$ in fractions 13-19 (Figure 1). These SPI containing fractions were pooled for further analysis. A minor proportion of the total sulfated glycosaminoglycan (GAG) of the extract was also eluted in the pooled SPI fractions, however the majority of the sulfated GAG eluted at $2 \mathrm{M} \mathrm{NaCl}$ in the step change of the elution profile. This represented aggrecan, the major AC CS-proteoglycan (Figure 1). This initial step was useful to separate the cartilage SPI from aggrecan a major cartilage protein which otherwise interferes with further analysis of the SPIs.

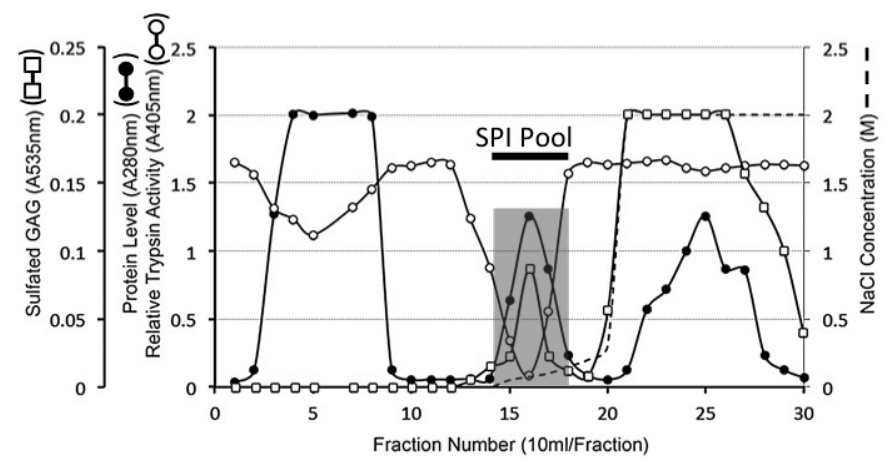

Figure 1. Diethylaminoethyl (DEAE) Anion exchange chromatography of a $6 \mathrm{M}$ urea extract of ovine articular cartilage showing protein (A280 nm), sulfated glycosaminoglycan (A535 nm), and relative trypsin inhibitory activity of the fractions (A405 nm). The column was eluted with a gradient of $\mathrm{NaCl}$ (dotted line). Fractions displaying serine proteinase inhibitor (SPI) activity were pooled as shown for further purification.

The DEAE SPI pool was next subjected to HA affinity chromatography (Figure 2). A small proportion of SPI and major proportion of protein did not bind under the chromatographic conditions used however the majority of the extracted AC SPI displayed an affinity for HA and was subsequently eluted with $2 \mathrm{M} \mathrm{NaCl}$ (Figure 2).

Sephadex G100 gel permeation chromatography of the HA affinity bound SPI resulted in the elution of $\sim 30 \%$ of the SPI in the void volume of the column (Fraction $4-8$ ) while a larger proportion of the SPI eluted well included into the column over fractions 18-26 (Figure 3a). These SPI containing fractions were separately pooled (SPI pool 1 and SPI pool 2) and stored at $4{ }^{\circ} \mathrm{C}$ for one month prior to re-chromatography on the same column (Figure $3 b, c)$. The void volume SPI pool sample eluted as two discernable SPI peaks at the void volume and also in fractions 12-16 (Figure 3b). The SPI pool 2 sample from the initial separation on Sephadex G100 (Figure 3a) eluted over a similar size range after storage however the SPI activity profile of this peak was skewed towards a smaller molecular weight range and an additional SPI peak was evident in fractions 32-38 (Figure 3c). 


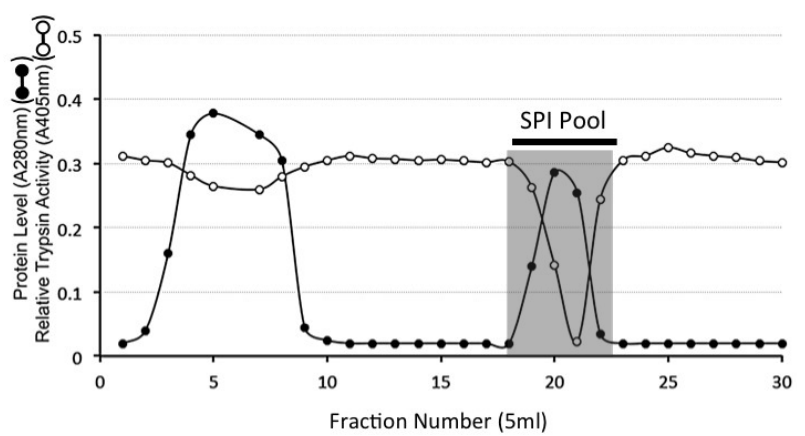

Figure 2. Hyaluronan (HA) affinity chromatography of the serine proteinase inhibitor (SPI) pool from DEAE Anion exchange chromatography of the ovine AC SPIs. The column was eluted with 2 bed volumes of starting buffer $50 \mathrm{mM}$ Tri- $\mathrm{HCl}$ pH 7.2 and the bound SPI eluted by a step change elution with $2 \mathrm{M} \mathrm{NaCl}$ in starting buffer. Fractions containing trypsin inhibitory activity were pooled (SPI pool) for further analysis.

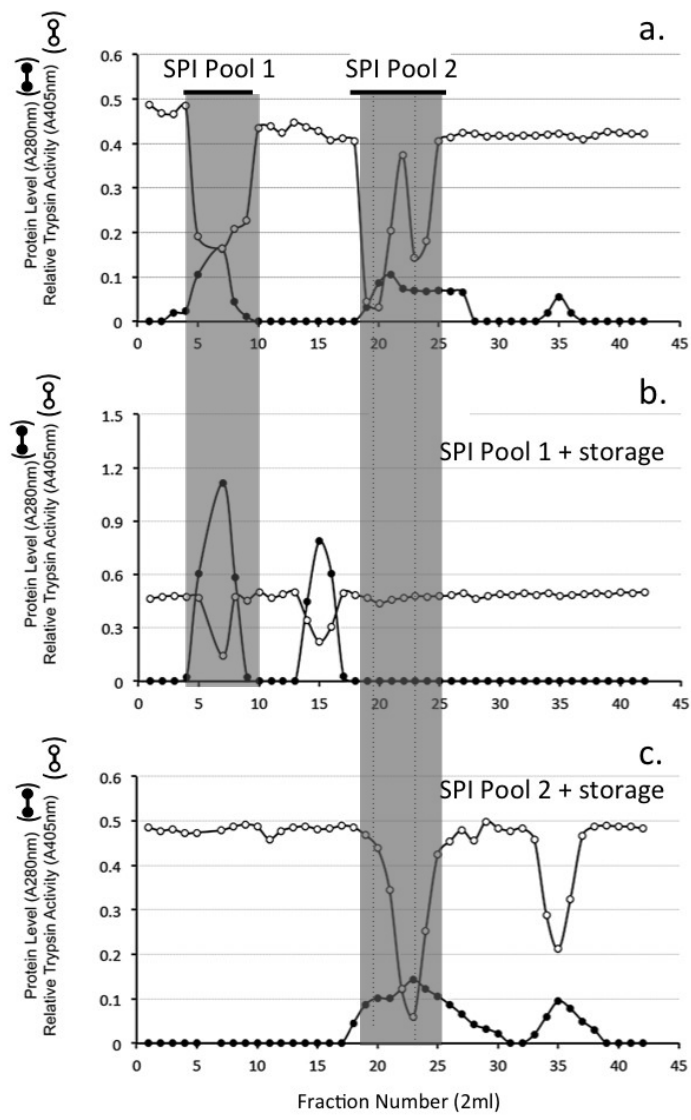

Figure 3. Sephadex G100 gel permeation chromatography of the ovine articular cartilage (AC) SPI sample from HA affinity chromatography (a) Fractions were monitored for protein (A280 nm) and relative trypsin inhibitory activity (A405 nm). Fractions containing trypsin inhibitory activity were pooled. Two SPI pools were collected as shown and separately re-chromatographed on the same column after 2 weeks storage at $4{ }^{\circ} \mathrm{C}(\mathbf{b}, \mathbf{c})$.

Samples of the SPI pools 1 and 2 from Sephadex G100 gel chromatography of the ovine AC SPI (Figure 3a) were subjected to chymotrypsin affinity chromatography. All detectable SPI activity was bound to this affinity matrix and eluted over fractions 20-25 (Figure 4). Affinity blotting using bT of the Sephadex G100 SPI pool 1 and 2 samples prior to and after chymotrypsin affinity identified major $120 \mathrm{kDa}$ SPI (SPI120) and 36-58 kDa SPIs (SPI58) which were converted to a $12 \mathrm{kDa}$ SPI species by the affinity procedure (Figure 4 insets). 

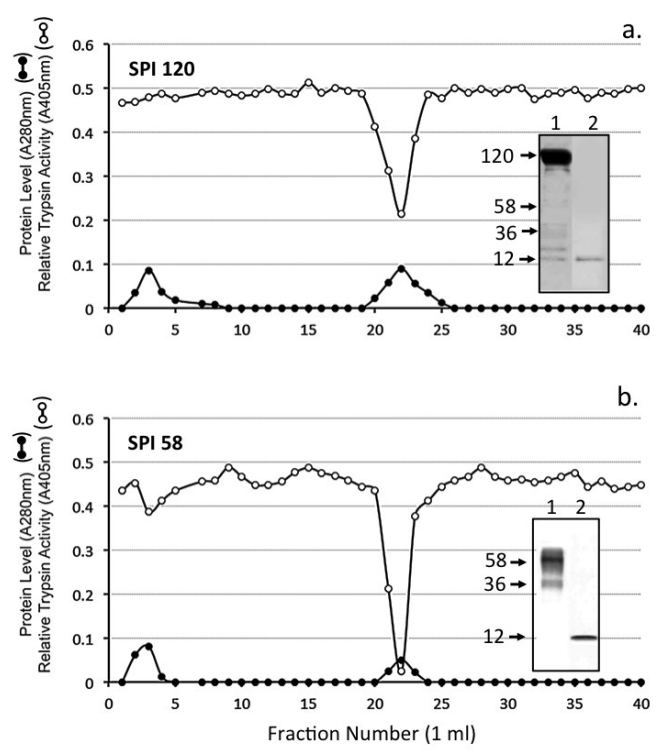

Figure 4. Chymotrypsin affinity chromatography of the SPI 120 (a) and SPI 58 (b) SPI pools 1 and 2 from Figure 3a. The insets depict biotinylated trypsin (bT) affinity blots, which identify active SPIs in the sample prior to (1) and after (2) chymotrypsin affinity chromatography.

Concanavalin A lectin affinity chromatography of the SPI58 sample from Sephadex G100 chromatography (SPI Pool 2, Figure 3a) resulted in the isolation of a bound SPI pool containing a closely spaced SPI doublet ( $45-58 \mathrm{kDa}$ ) and minor $36 \mathrm{kDa}$ species (Figure 5 ).

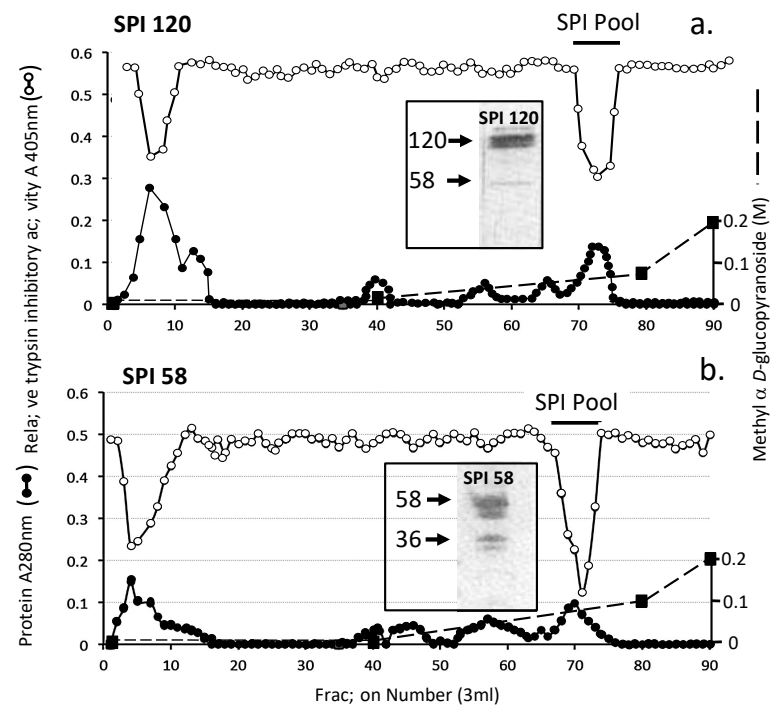

Figure 5. Concanavalin A affinity chromatography of SPI 120 (a) and SPI 58 (b) SPI pool 2 Figure 3a. The SPI58 pool was applied and the column eluted with 10 bed volumes of starting buffer ( $50 \mathrm{mM}$ Tris, $200 \mathrm{mM} \mathrm{NaCl}$ buffer $\mathrm{pH} 7.2$ starting buffer containing $1 \mathrm{mM} \mathrm{CaCl}_{2}, 1 \mathrm{mM} \mathrm{MgCl}$, and $1 \mathrm{mM}$ $\mathrm{MnCl}_{2}$ ). Bound material was eluted with a linear $0-0.2 \mathrm{M}$ gradient of methyl $\alpha$-glucopyranoside as shown. The inset shows active 58 and $36 \mathrm{kDa}$ SPIs on bT affinity blots of the SPI58 sample prior to and after Concanavalin A affinity chromatography.

Affinity blotting of SPI samples from various stages of the isolation procedure, (1) anion exchange, (2) HA affinity, (3-6) Sephadex G100 chromatography SPI pools 1 and $2 \pm$ storage at $4{ }^{\circ} \mathrm{C}$ and $[7,8]$ after chymotrypsin affinity identified a range of SPI species of molecular weight 120, 86, 58, 36, 26 and $12 \mathrm{kDa}$ (Figure 6a). Western blotting using antibodies to the 2-B-6 stub epitope of the CS side chain of bikunin. $\alpha 1$-microglobulin, bikunin and TSG-6 identified the molecular organisation of these SPIs. 
Selected regions of replicate blot lanes from anion exchange isolated ovine cartilage SPIs were cut into regions corresponding to the 120,58, 36 and $12 \mathrm{kDa}$ SPI bands and examined using antibodies to the chondroitin-4 sulfate stub epitope of CS chains (2B6 (+)), $\alpha 1$-microglobulin $(\alpha 1-\mathrm{M})$, bikunin and TSG-6. The blot segments for the 2B6 (+) determinations were digested overnight with chondroitinase $\mathrm{ABC}$ during the blocking step. This removes the CS chains generating a 2B6 (+) stub epitope which identifies CS substitution on that SPI species which migrates with the position of the intact CS-SPI during SDS PAGE. A summary of the antibody staining's for each SPI band is provided in Table C. Comparison of a bikunin blot (lanes 1-3) and bT affinity blot (lanes (4-6) of serum, plasma and urine samples. The smaller SPI species in lane 5 not detected in lane 2 is due to $\alpha 1$-proteinase inhibitor which binds to the HA affinity column during the isolation steps. Diagrammatic representations of the structural organisation of bikunin/ITI and the deduced inter-relationships between the KPIs identified in the present study are presented in Figures 7 and 8.

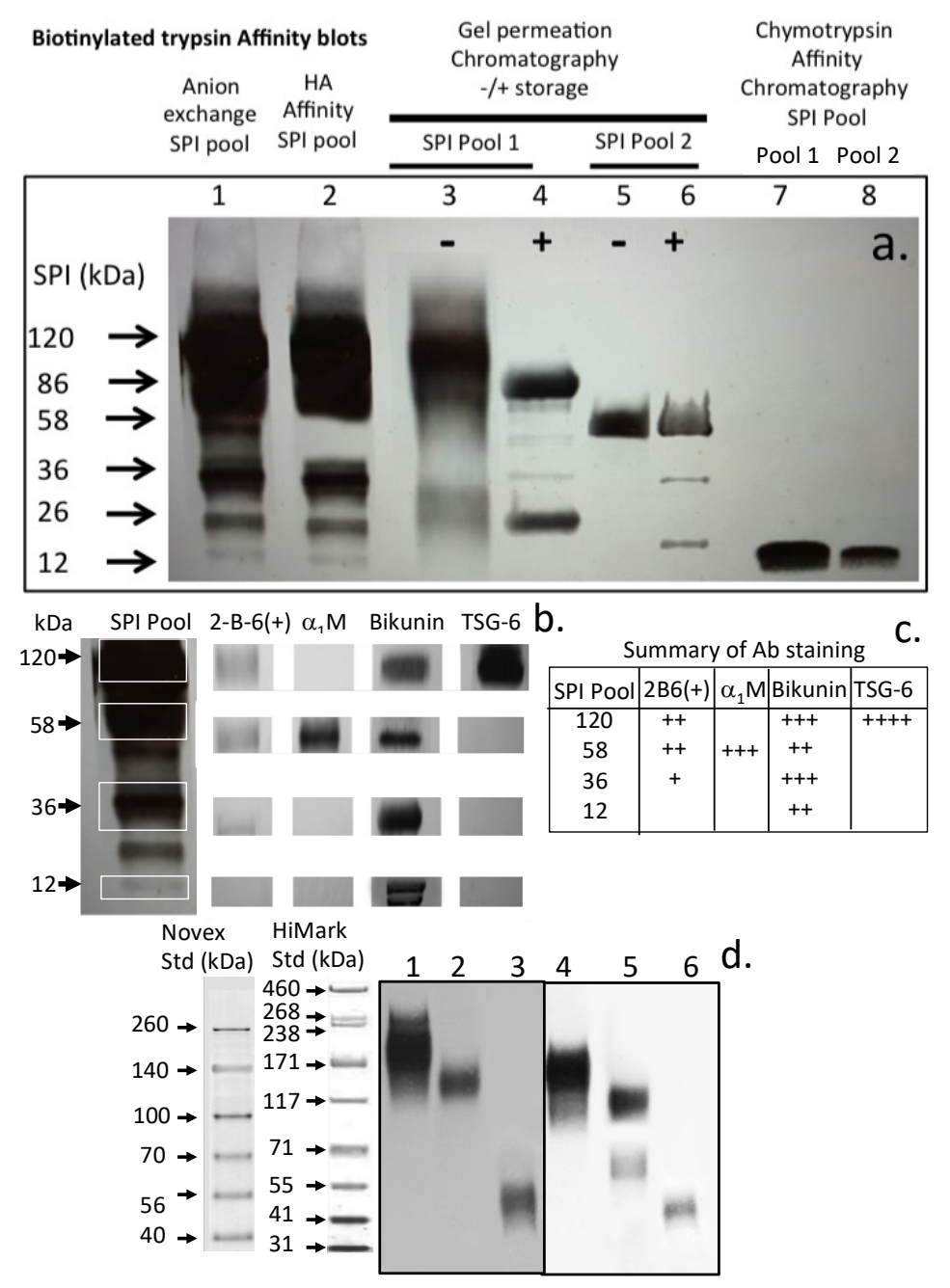

Figure 6. Identification of serine proteinase inhibitor (SPI) species using biotinylated trypsin and avidin alkaline phosphatase conjugate by affinity blotting in samples from the various isolation procedures used in this study (a) Selected bands were also identified using antibodies to CS (2-B-6 (+)), $\alpha 1 \mathrm{M}$, Bikunin, and TSG-6 (b) and the blot intensities summarized in the Table in (c). ITI and pre- $\alpha$-TI present in ovine plasma (lanes 1, 2, 4,5) and UTI in urine (lanes 3, 6) were also identified by Western blotting using antibodies to ITI (lanes 1,2) and bikunin (lane 3) and by affinity blotting using bT (lanes 4-6) (d). The extra band in lane 5 but not in lane 2 in segment (d) is due to $\alpha 1$-proteinase inhibitor which also displays an affinity for HA thus is also included in the pre- $\alpha$-TI pool taken from Sephadex G200 chromatography in our isolation scheme. 
a. Li et al 2011 b. Lord et al 2013 c. CS Disaccharides

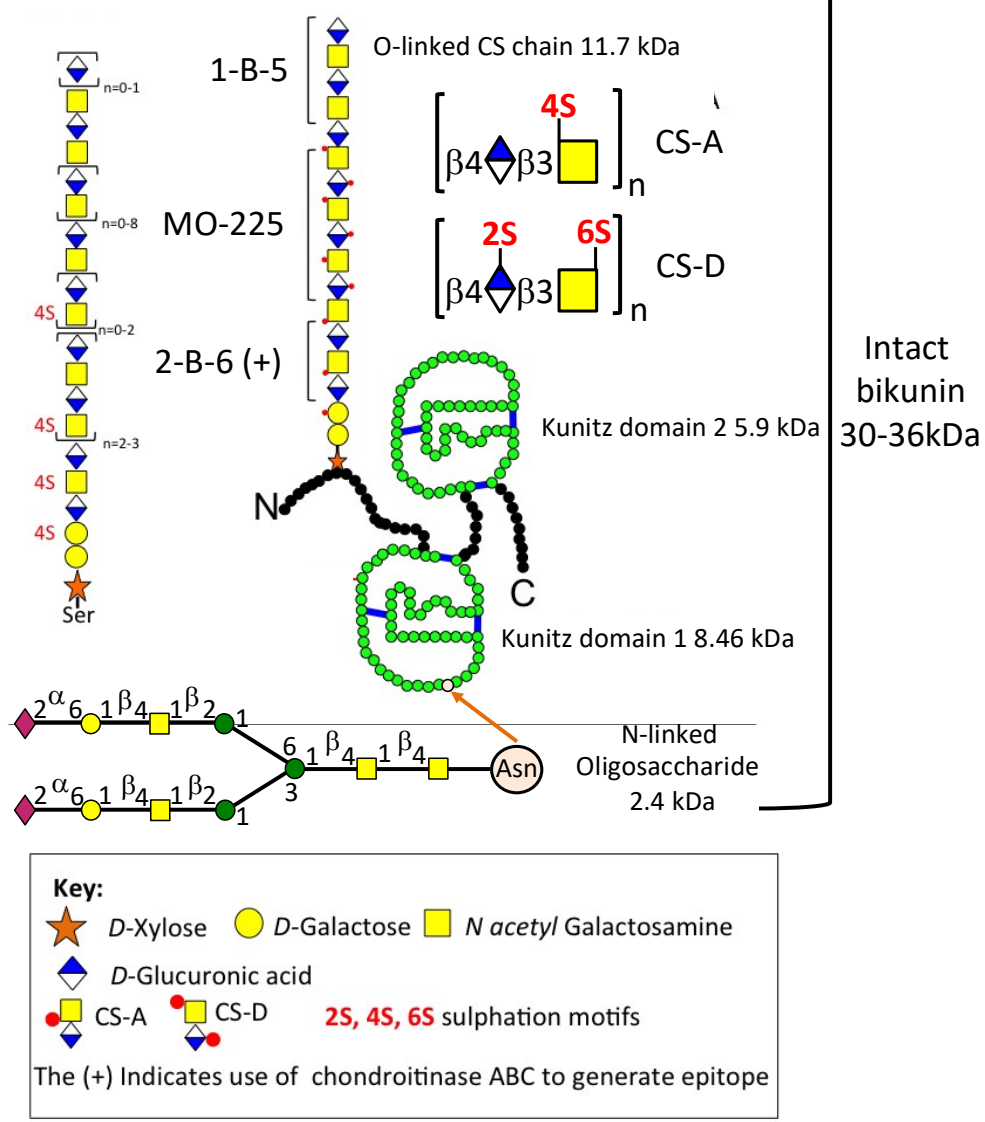

Figure 7. Sequence of the CS chain of bikunin as proposed by Ly et al. 2011 [11] (a) and Lord et al. 2013 [10] (b). The KPI SPI domains are shown in (b). and the attached N-glycan chain of KPI-1. The over-sulfated CS-D disaccharide is shown which forms part of the MO-225 epitope embedded in the CS-A chain of bikunin. Arrangement of sulfated, disulfated and non-sulfated regions of the CS chain of bikunin are shown. The arrow shows the Asparagine residue on Kunitz domain 1.

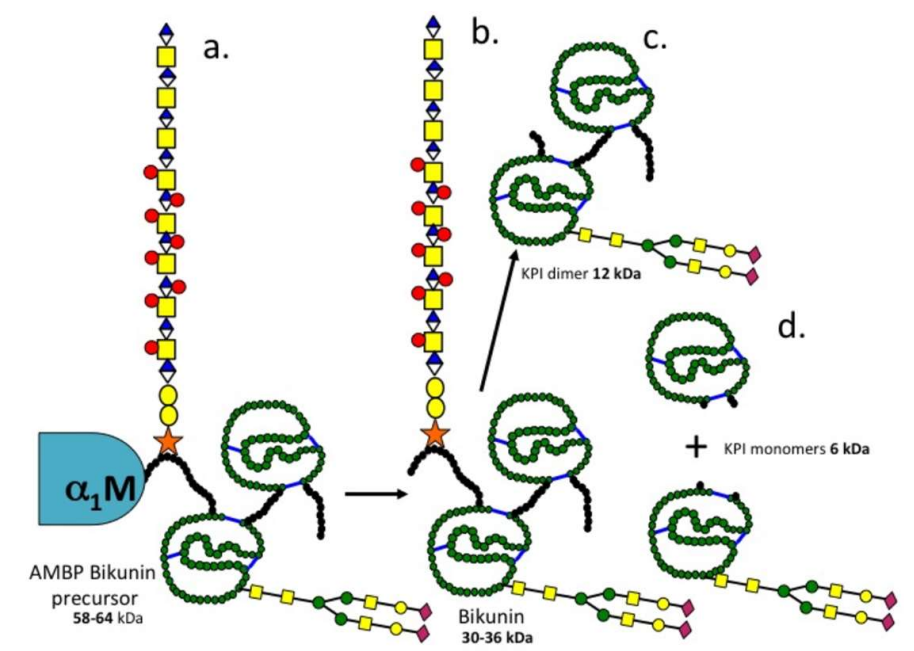

Figure 8. Schematic representations and proposed inter relationship between SPI species seen in this study. a. $\alpha 1$ microglobulin-bikunin precursor (58-64 kDa), b. bikunin 30-36 kDa, c. bikunin KPI dimer (12-16 kDa) after removal of the $11.7 \mathrm{kDa}$ CS chain from bikunin, d. bikunin KPI monomers (6-9 kDa) with the N-linked 2-4 kDa glycan oligosaccharide attached to the KPI-1 domain which facilitates its isolation by ConA affinity chromatography and the $6 \mathrm{kDa}$ KPI-2 domain which does contain oligosaccharide substitution. 
Assessment of the inhibitory activity of the isolated KP1 and KP2 ITI SPI domains against a range of serine proteinases using specific anilide substrates demonstrated these had potent inhibitory activity against porcine pancreatic trypsin and chymotrypsin, human leucocyte elastase and cathepsin G, porcine kallikrein and plasmin comparable to BPTI (Table 1). KPI-1 was less inhibitory against human leucocyte cathepsin G, porcine kallikrein and plasmin compared to BPTI however still displayed appreciable inhibitory activity against these proteinases (Table 2).

Table 1. Serine proteinase inhibitory (SPI) activities of the Bikunin Kunitz protease inhibitor (KPI) domains and bovine pancreatic trypsin inhibitor (BPTI).

\begin{tabular}{|c|c|c|c|c|}
\hline \multirow[t]{2}{*}{ Proteinase } & \multirow[t]{2}{*}{ Substrate * } & \multicolumn{3}{|c|}{$\begin{array}{c}\text { Mean Relative Inhibitory Activity by } 1 \text { Unit of SPI ** } \\
\text { (\% Inhibition) } \pm \operatorname{SD}(n=6)\end{array}$} \\
\hline & & Sheep Kunitz Domain 1 & Sheep Kunitz Domain 2 & BPTI \\
\hline Porcine Pancreatic chymotrypsin & AAVANA & $52 \pm 4.05$ & $55 \pm 2.86$ & $53 \pm 3.73$ \\
\hline Human Leucocyte elastase & SAAVNA & $67 \pm 4.79$ & $69 \pm 3.06$ & $78 \pm 4.07$ \\
\hline Human Leucocyte cathepsin G & SAAPPNA & $18 \pm 7.09$ & $25 \pm 5.01$ & $28 \pm 4.03$ \\
\hline Porcine Plasmin & VLLNA & $51 \pm 4.84$ & $85 \pm 1.94$ & $88 \pm 8.84$ \\
\hline
\end{tabular}

** One unit of inhibitory activity was defined as the amount of SPI required to give $50 \%$ inhibition of $0.2 \mu \mathrm{g}$ of active site titrated trypsin. Each proteinase $(0.2 \mu \mathrm{g})$ was incubated with one unit of SPI and residual enzyme activity assessed relative to enzyme samples incubated in the absence of inhibitor using the indicated substrates. * Abbreviations: ZAPNA: CBZ-Arg-4 NA; AAVANA: Ala-Ala-Val-Ala 4-NA; SAAVNA: N-Succinyl-Ala-Ala-Val-4NA, SAAPPNA: N-Succinyl-Ala-Ala-Pro-Phe 4-NA; VLANA: D-Val-Leu-Arg 4NA; VLLNA: D-Val-Leu-Lys 4NA; SPI: Serine proteinase inhibitor; KPI: Kunitz protease inhibitor.

Table 2. Serine proteinase inhibitory activities of the Bikunin Kunitz KPI domains and BPTI.

\begin{tabular}{ccc}
\hline Proteinase & \multicolumn{2}{c}{ Statistical Significance } \\
\hline Porcine pancreatic trypsin & KPI-1 vs. BPTI & KPI-2 vs. BPTI \\
\hline Porcine Pancreatic chymotrypsin & NSD & NSD \\
Human Leucocyte elastase & NSD & NSD \\
Human Leucocyte cathepsin G & NSD & NSD \\
Porcine Kallikrein & KPI- $1<$ BPTI; $p<0.05$ & NSD \\
Porcine Plasmin & KPI- $1<$ BPTI $p<0.05$ & NSD \\
\end{tabular}

Versican was prominently immunolocalised in the surface regions of bovine knee articular cartilage, as was PRG4 (Figure 9a). Biotin labelled hyaluronan binding protein (bHABP) was used to localise HA, this was visualised using an avidin-FITC secondary reagent (Figure 9b). Lubricin was immunolocalised using MAb 3A4 and an Alexa 488 conjugated secondary antibody (Figure 9c). 


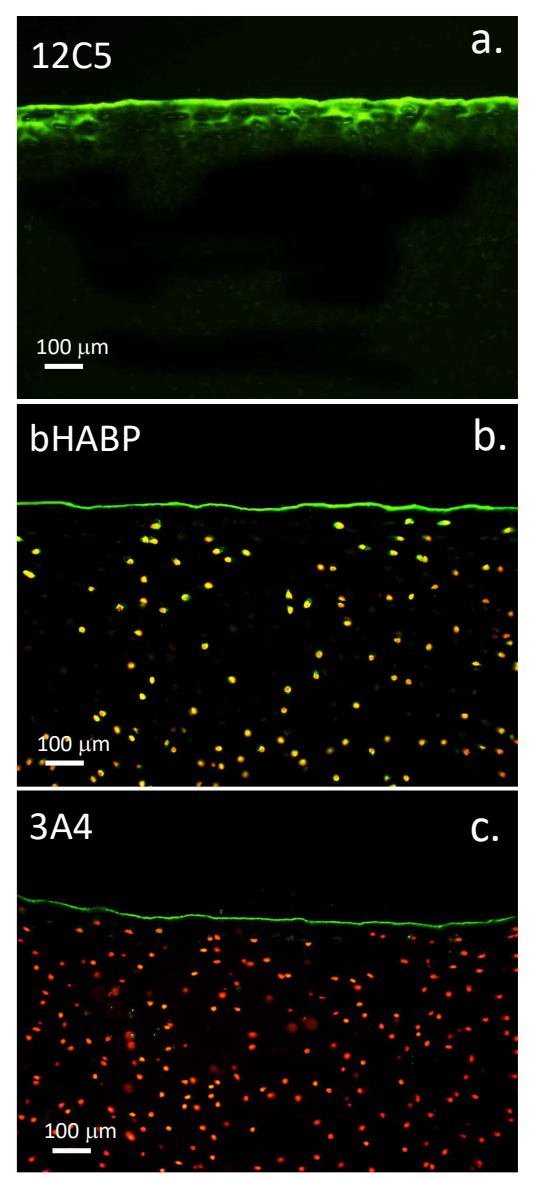

Figure 9. Immunolocalisation of versican in the surface regions of tibial plateau bovine articular cartilage (a) immobilises HA at the cell surface (b). This is visualised using biotinylated HABP and avidin-FITC. Lubricin is also a component of the surface lamina of articular cartilage (c) and has roles in joint lubrication acting synergistically with HA and other proteins such as fibronectin and pentraxin-3 which aid in joint lubrication. ITI SPIs are also attached to HA and these protect the cell surface lubricin. HA is also visualised intra- and pericellularly in the articular chondrocytes (b). Cell nuclei were stained with propidium iodide in $\mathrm{b}$ and $\mathrm{c}$. HA was visualised using bHABP/avidin-FITC. The fluorescent images were visualised by confocal microscopy using a Leica TCS SP2 AOBS laser scanning confocal microscope using a $40 \times$ oil immersion objective. The slides were scanned using excitation and emission settings for Alexa 488 of (Ex max: 488; Em max: 520) Z-stacks of 8-bit 'optical sections' (512 $\times 512$ pixels) were taken through the full cartilage thickness at in $0.4 \mu \mathrm{m}$ increments. 'Maximum Intensity' reconstructions were prepared from the image stacks using Leica Confocal Software (Leica, Heidelberg, Germany).

\section{Discussion}

\subsection{Identity of the Ovine Cartilage SPIs}

The present study has identified a $58 \mathrm{kDa} \alpha 1$-microglobulin-bikunin precursor protein (SPI 58) which was converted to a number of smaller SPIs either by prolonged storage or by chymotrypsin affinity chromatography [18,21]. A $120 \mathrm{kDa}$ SPI was also detected which had the CS attachment stub epitope identified by MAb 2-B-6 (+) and was also reactive with antibodies to bikunin and TSG-6 consistent with its identity as pre- $\alpha$-TI. All of the SPIs generated from SPI 58 were reactive with an antibody to bikunin. A canine IVD study has previously identified 120-250 kDa SPIs cross-reactive with an ITI antibody [31]. Pre- $\alpha$-TI is susceptible to cleavage by kallikrein into 100 and $35 \mathrm{kDa}$ fragments [6] and trypsin also degrades ITI into a number of characteristic fragments of similar size to those seen in the present study [64]. The ovine cartilage SPI 58 and 120 was also isolated by concanavalin A 
lectin affinity chromatography confirming $N$-glycosylation known to be present on bikunin. SPI 26 was also isolated using concanavalin A lectin affinity chromatography, SPI-26 was also reactive with anti-bikunin but not antibodies to 2-B-6 (+), $\alpha 1-\mathrm{M}$ or TSG-6 thus identifying this as a KPI dimer devoid of the CS chain of bikunin.

\subsection{The Structural Organisation of Bikunin}

Bikunin is the simplest proteoglycan known, consisting of a 146 amino acid core protein, which is synthesised as a 337 amino acid $58 \mathrm{kDa} \alpha 1$-microglobulin-bikunin precursor protein (AMBP) which is cleaved at Arg-186 to release $\alpha 1$-microglobulin and bikunin. Bikunin is glycosylated at Ser- 10 with a single heterogeneous $O$-linked 15-25 kDa chondroitin-4-sulfate chain containing 23-55 saccharide residues; a biantennary $N$-linked glycan is also attached at Asn- 45 . The $16 \mathrm{kDa}$ bikunin core protein is organised into two $6 \mathrm{kDa}$ Kunitz protease inhibitor domains which are each stabilised by three internal disulphide bonds [65]. The schematic in Figure 7 depicts the CS side chain organisation and its attachment to bikunin as proposed by Ly et al. [11], Lord et al. [10] and Fries and Blom [32]. Ly et al. identified the consensus sequence of the CS-A chain of bikunin concluding that the identification of the precise sequence of this CS chain was a difficult proposition due to its micro-heterogeneity. Lord et al. subsequently went on to demonstrate embedded CS-D disaccharides within the CS-A chain using monoclonal antibody MO-225, these are considered important for the interactive properties of the bikunin CS chain [10]. The general depiction of the bikunin molecule by Fries and Blom [32] shows the $\mathrm{O}$-linked CS chain in the $\mathrm{N}$-terminal extension peptide of KPI domain 1 and $\mathrm{N}$-glycosylation site at Asn-45 [10,11].

\subsection{Inter-Relationships between Ovine Articular Cartilage SPI Species and Bikunin/ITI}

Comparison of data generated in the present study with published data on ITI fragments generated by trypsin or kallikrein digestion allowed us to interpret inter-relationships between the ovine AC SPIs observed in the present study. A diagram of the deduced structures of these SPIs is presented in Figure 8. SPI58 was detected using antibodies to $\alpha 1$-microglobulin, bikunin and 2-B-6 (+) CS stub epitope thus represented the CS substituted AMBP-bikunin precursor protein. Chymotrypsin affinity chromatography generated 12 and $6 \mathrm{kDa}$ SPIs from SPI58. This protein appears quite labile and prolonged storage of SPI58 at $4{ }^{\circ} \mathrm{C}$ also generated 36, 26 and $12 \mathrm{kDa}$ KPI species, these were identified by a polyclonal anti-bikunin antibody, SPI36 contained a 2-B-6 (+) reactive CS epitope demonstrating the presence of a CS side chain while SPI26 did not, but contained variable portions of the $\mathrm{N}$ and $\mathrm{C}$ terminal peptide extensions attached to the KPI dimer. We also deduced that SPI12 represented the double headed KPI devoid of these peptide extensions. Furthermore, SPI6 could be generated by chymotrypsin affinity representing individual KPI domains 1 and 2, these were separable from one another using concanavalin-A lectin chromatography on the basis of the absence or presence of $N$-glycosylation.

\subsection{ITI/Bikunin Is A Multifunctional Protein}

Despite its discovery almost six decades ago the primary role of ITI has been elusive. Subsequent studies have established functional roles for the ITI HC and KPI domains in their own right. While the KPI domains of the bikunin light chain of ITI confer protease-inhibitory properties they also provide anti-tumour and anti-viral properties. Furthermore, the HCs attached to the CS chain of bikunin mediate ITI's protein-protein interactions with many ECM components. TSG6 is one such interactive protein, which promotes the transfer of the ITI HCs to HA, cross-linking and stabilising HA through a unique trans-esterification reaction [66]. In some cases, the accumulation of HA-HCs in tissues can be beneficial such as in the ripening and fertilisation of the oocyte or the maturation of the growth plate cartilages during endochondral ossification [39-41,67]. In other cases, HC-HA accumulation in a condensed form in tissues hampers tissue function. Besides AC, ITI is also expressed in brain, placenta, liver, heart, lung, kidney and IVD and may be of importance in organ development $[19,38]$. Several 
observations suggest that like other members of the KPI superfamily, bikunin has anti-tumour and anti-viral activities, expression of bikunin by human glioblastoma cells suppresses tumour invasion [68] and addition of bikunin to human chondrosarcoma cell cultures blocks cell spreading [69]. Prior to this, low molecular weight factors had been detected in pregnant urine and pharmaceutical grade preparations of human chorionic gonadotrophin (hCG) which actively inhibited Kaposi Sarcoma (KS) lesion development in HIV infections. These factors were initially termed antiviral lysozyme-C or antiviral RNases [70-74]. The appreciation that bikunin possessed anti-viral activity became apparent when a $15.8 \mathrm{kDa}$ fragment of bikunin was identified as a contaminant in hCG preparations which inhibited the spread of KS lesions in HIV infections [75].

\subsection{Detrimental Aspects of HC-HA Complex Transfer in Tissues}

During inflammation and developmental processes, HCs from ITI are covalently transferred to HA via the enzyme TSG-6 to form an HC-HA complex. This is a significantly more adhesive substrate for leukocytes than non-cross-linked HA, and can enhance inflammation in pathological conditions. The accumulation of pro-inflammatory HC-HA in lung tissue in cystic fibrosis exacerbates chronic inflammation in airway disease and increases mucus viscosity making it difficult to eliminate from the bronchioles reducing $\mathrm{O}_{2}$ transfer and impairing lung function [76]. Hyperglycemia induces accumulation of HA around vascular smooth muscle cells, increases aortic stiffness and strength, and primes the vascular wall for the deposition of cholesterol, accumulation of leucocytes and accelerated development of atherosclerosis in $\mathrm{ApoE}^{-/-}$mice [77]. Accumulation of HA and HC-HA in lung tissue correlates with impaired lung function in asthma and the inflammation of lung tissues [78]. With the development of type I diabetes, HA is dramatically increased within and outside the islet pancreatic endocrine cells, contributing to the pathogenesis of diabetes [79]. ITI HC proteins accumulate in tumours and are implicated in their pathogenesis [80,81]. Renal epithelial cells produce bikunin when stimulated by nephrotoxic agents such as oxalate [82], HA also inhibits calcium oxalate crystallisation in vitro [83]. Urinary trypsin inhibitor (UTI) has a regulatory effect on local vascular tone by regulation of Ca2+ influx suppressing smooth muscle contraction [84] and also prevents lipopolysaccharide-induced increases in cytosolic free $\mathrm{Ca} 2+$ in human neutrophils and human umbilical vein endothelial cells [85].

The KPI proteins are a diverse group of proteins occurring in all phyla in nature. Many invertebrate KPIs display blocking properties for voltage gated ion-channels. The parasitic worm Echinococcus granulosus synthesises a KPI peptide that blocks cation channels [86]. ShPI-1 and APEKTx1, BPTI-like KPIs from the sea anemones Stichodactyla helianthus [53] and Anthopleura elegantissima [55] and the anemone toxins kalicludines and kaliseptine are homologous to snake venom dendrotoxins and also display ion-blocking properties [56]. Calcicludine, a venom peptide of Dendroaspis angusticeps, homologous to snake dendrotoxins and the KPI APP/protease nexin-2 domain of the brain proteoglycan appican $[54,87]$ blocks high-threshold Ca2+ channels in cerebellar granule neurons [57] and homologous to LmKTT-1a a bifunctional KPI and potassium channel blocking scorpion peptide toxin [88]. The snake toxin BF9 also displays KPI activity and potassium channel inhibitory activity [58]. These ion-blocking properties are related to the neuroregulatory properties displayed by bikunin and appican in the CNS.

\subsection{Tissue Isoforms of ITI}

Serum ITI has historically been depicted as a molecule containing two heavy chains (HC1 and HC2) while pre- $\alpha$-TI has another HC (HC3) however up to six HCs can be attached to the CS chain of bikunin/ITI with tissue development and pathology [89]. A systematic review of gene and transcript expression profiles using microarray and sequencing based functional genomics and antibody-based profiling [90-94] is working towards a full description of a tissue-based map of the human proteome [95]. Thus, a comparison of the expression profiles of the ITIH1-ITIH5 genes in tissues demonstrates that ITIH1-ITIH4 are predominantly expressed in liver while ITIH5 is expressed 
in breast, skin, adipose tissue and placenta $[15,89]$. ITIH5 is over-expressed in inflammatory skin diseases such as psoriasis, atopic dermatitis and allergic contact dermatitis [15] and specifically in the suprabasal layers of the epidermis. ITIH5 is also expressed by normal skin fibroblasts but not by epidermal keratinocytes [89] and is a novel putative tumour suppressor gene in colon cancer [96]. Renal ITIH3 expression may regulate oxalate kidney stone formation [83]. HA also inhibits calcium oxalate crystallisation in vitro [83]. Novel truncated $50 \mathrm{kDa}$ forms of $\mathrm{HC} 1$ and $\mathrm{HC} 2$ have been detected in OA AC [16], full length $90 \mathrm{kDa}$ HCs attached to HA were also observed in the synovial fluids of OA patients. Bikunin and ITI are abundant in regions of surface fibrillation in OA AC.

\subsection{Beneficial Aspects of HC-HA Transfer in Connective Tissues}

Mesenchymal stem cells (MSCs) are pluripotent, differentiating into osteoblasts, chondrocytes, and adipocytes in vitro and in vivo. Umbilical MSCs (UMSCs) exposed to inflammatory cells synthesise an extracellular glycocalyx rich in HA bound to ITI HCs and the enzyme TSG6 which catalyses the transfer of HCs to HA, versican, and pentraxin-3 [97]. This glycocalyx regulates inflammatory cells and allows UMSCs to survive host immune rejection. Furthermore, the focal up-regulation of HA and ITI in areas of muscle damage and the temporal acute expression of TSG6 by MSCs is conducive to the creation of a microenvironment favoring the engraftment of MSCs in areas of damaged muscle promoting tissue repair [98].

\subsection{Protective Roles for ITI KPIs in Connective Tissues}

MMPs have important roles in tissue remodeling in physiological and pathological conditions in tissue development, morphogenesis, angiogenesis, tissue repair, arthritis and in tumour development. AC SPIs have roles in the prevention of excessive degradation of ECM components following traumatic overload in post-traumatic OA or in the inflammatory conditions of RA. Kunitz domain 2 of ITI (trypstatin) is taken up by mast cells and is found complexed with serine proteases in intracellular granules [99].

\subsection{KPIs in Meniscus, $A C$ and IVD}

The human, canine and ovine IVD contain both low molecular weight (12 kDa) SPIs and 120 and $250 \mathrm{kDa}$ ITI-like SPIs [28,31] active against human leucocyte elastase (HLE), cathepsin-G, chymotrypsin and trypsin, urokinase, plasmin, kallikrein [100], similar SPIs have been identified in costal and AC and fibrocartilaginous meniscus [25]. N-terminal sequencing demonstrated identical amino acid sequences for the cartilage and IVD SPI with SLPI from parotid and seminal plasma secretions [25]. IVD cells and articular chondrocytes also synthesised mRNA to SLPI [59]. Affinity blotting with bT [24], a solid phase enzyme linked immunofiltration assay to SLPI [101] and competitive inhibition assay developed to quantitate SPIs in normal and degenerate human IVDs [30], demonstrated depleted levels of active IVD SPI with advancing IVD pathology. Studies on canine IVD SPIs in chondrodystrophic (ChD) and non-chondrodystrophic (non-ChD) breeds [31] have differing rates of disc degeneration and an age dependent decline in active IVD SPI levels in the $\mathrm{ChD}$ (but not the non-ChD) breeds. BPTI has similar electrophoretic properties to the $6 \mathrm{kDa}$ ovine AC SPI [21]. A chicken anti-BPTI IgY demonstrated homologies between the ovine SPIs and BPTI [28] and immunolocalised these in mast cells and chondrocytes in ovine and bovine lung and AC [29]. BPTI cross-reactive SPIs were synthesised by ovine AF and NP cells in alginate bead culture with a $6 \mathrm{kDa}$ SPI secreted into the culture media and a 34-36 kDa SPI was retained within alginate beads [19]. Ovine chondrocytes also synthesised ${ }^{14} \mathrm{C}$-lysine- 6 and $58 \mathrm{kDa}$ SPIs in alginate bead culture [18]. A biotinylated potato chymotrypsin inhibitor affinity probe demonstrated that chondrocytes synthesised an active ${ }^{14} \mathrm{C}$-chymotrypsin-like serine proteinase in alginate bead culture [20], which may generate the $6 \mathrm{kDa}$ ovine Kunitz SPI from the 58-kDa SPI precursors. 


\subsection{Bikunin As A Cell Regulatory Proteoglycan}

Oversulfated CS/DS promotes neuritogenesis and regulates CNS development. The disulfated disaccharide CS-D-unit, promotes neurite outgrowth through the DSD-1 epitope embedded in the CS chains of DSD-1-PG/phosphacan [100-106]. Over sulfated DS also exhibits neurite outgrowth activity [107], the short isoform variant of phosphacan/receptor protein tyrosine phosphatase- $\beta$, interacts with neuronal receptors and promotes neurite outgrowth [108]. Bikunin is also expressed in brain tissue [107,109] and accumulates in brain tumours [81]. Like phosphacan, bikunin contains embedded CS-D motifs within the repeat disaccharide region of its CS chain. Such motifs in phosphacan promote neurite outgrowth suggesting that bikunin may also have roles to play in neural development. Appican is another CS brain proteoglycan containing embedded CS-E residues within its CS side chains $[87,110]$ and is produced by astrocytes [111]. These CS-E motifs [112] interact with neuroregulatory factors [113] inducing morphological change in C6 glioma cells and directed adhesions of neural cells to the ECM [114] and also promote the chondrocytic differentiation of ATDC5 cells [115]. HC chain transfer from the bikunin CS chain provides matrix stabilisation, oocyte expansion and is essential in fertilisation but CS-HCs may affect HA turnover adversely and have deleterious effects on physiological processes in cystic fibrosis, diabetes, asthma, hyperglycemia, tumour development and atherosclerosis. Microarray analysis has identified a number of bikunin target genes in ovarian cancer cells and these have been categorised as transcriptional regulators, oncogenes/tumour suppressor genes, signaling molecules, growth/cell cycle, invasion/metastasis, cytokines, apoptosis, ion channels, extracellular matrix proteins, as well as some proteases [116]. This further emphasises bikunin as a multifunctional cell regulatory proteoglycan.

\subsection{Localisation of HA and ITI SPIs at the Articular Surface Is of Physiological Significance}

Versican is found localised at the surface of AC where it localises HA. As shown in this study, the ITI SPIs share an affinity for HA thus we may deduce that these would also localise in the surface regions of $\mathrm{AC}$ where they would protect the AC from proteolytic damage from serine proteinases. The ITI SPIs have broad inhibitory activity against a range of serine proteinases (Tables 1 and 2) some of which have MMP activating activity, another class of cartilage degradative proteinase. The ITI SPIs also display potent ant-bacterial, ant-fungal and anti-viral activities further expanding putative biological protective roles in cartilaginous tissues.

Lubricin (PRG4) was also shown to be a component of the cartilage surface in the present study (Figure 9c); lubricin acts synergistically with HA (Figure 9b) to provide elastoviscous properties, which are important for the articulatory properties of articular cartilage [117]. HA in isolation is a relatively poor boundary lubricant. Localisation of the ITI SPIs with HA in the articular surface may protect lubricin in the surface lamina and make important contributions to the preservation of joint function. A number of catabolic enzymes have been observed which digest lubricin [118-120] and can be inhibited by ITI (Table 1). ITI accumulates in HA depositions in skin in a condition known as lichen sclerosis [121]. HA is depleted in AC in human OA and in a mouse model of human mucopolysaccharidosis IX which displays similar cartilage changes as found in OA [122]. In normal AC, HA is found localised to the articulatory surface regions and in the epiphyseal growth plate where it has roles to play in endochondral ossification. HA is also localised pericellularly and intracellularly in hypertrophic cells of the vertebral growth plate [123]. TSG-6 catalyses the transfer of HCs to HA, and may also transfer these to versican at the articular cartilage surface (Figure 9). ITI SPIs are also components of glycocalyx formations in the corneal surface under inflammatory conditions [124]. ITI isoforms attached to the articular surface may be attached to versican at the articular surface [16]. TSG-6 also catalyses the transfer of HC chains from ITI to stabilise amniotic membranes [125]. Pentraxin-3-HC-HA complexes have anti-angiogenic properties and roles in innate immunity complementing lubricin-TLR-2 and TLR-4 interactions in the cartilage surface to regulate inflammatory processes and maintain cartilage homeostasis [126,127]. Pentraxin-3 is a soluble pattern recognition receptor with roles to play in innate immunity $[128,129]$. High molecular weight HA 
also has anti-inflammatory properties [130]; its localisation at the cartilage surface contributes to joint lubrication. Lubricin in the surface regions of cartilage also binds to a number of cartilage proteins [131] contributing to joint lubrication, and the retention of lubricin at the cartilage surface [132] and may promote cartilage regeneration [133-135].

\section{Materials and Methods}

The sources and quality of reagents used in this study were as noted earlier $[18,20,21]$. Chondroitinase-ABC from Proteus vulgaris (Catalogue \# C3667), bovine pancreatic trypsin type XI, Porcine pancreatic trypsin and chymotrypsin, porcine kallikrein and porcine plasmin, human plasma $\alpha 1$-proteinase inhibitor were purchased from Sigma-Aldrich (Sydney, Australia). 1,9-dimethyl methylene blue was obtained from Sigma-Aldrich, Sydney, Australia. Nitroanilide chromogenic protease substrates were purchased from Bachem Feinchernikalien AG (Bubendorf, Switzerland). BPTI as Trasylol ${ }^{\circledR}$ (Aprotinin) was obtained from Bayer Healthcare through our in-house pharmacy (St Leonards, Australia). Human leucocyte elastase and cathepsin G were isolated from out of date neutrophil buffy coat preparations obtained from our blood bank (Sydney, Australia) as specified earlier [136,137]. Antibodies to $\alpha 1$-proteinase inhibitor (ab9373) and inter- $\alpha$-trypsin inhibitor (ab204513), rabbit polyclonal anti-bikunin antibody (ab43073) were purchased from Abcam, Cambridge, MA, USA. Affinity purified mouse monoclonal antibody to TSG-6 (Catalogue \# AF2326) and mouse anti-human $\alpha 1$-microglobulin (Catalogue \# MAB7724) were obtained from R \& D systems, In Vitro Technologies Pty Ltd., Melbourne, Vic, Australia. 2-B-6 Hybridoma conditioned medium and anti-lubricin (MAb 3A4) were gifts from Prof B. Caterson, University of Cardiff, Cardiff, UK. MAb 12C5 to versican G1 domain, was purchased from the Developmental Studies Hybridoma Bank, University of Iowa, Iowa city, IA, USA. Hyaluronan binding protein (HABP) was isolated from bovine nasal cartilage, biotinylated and used as indicated earlier [138,139].

\subsection{Tissues}

Ovine stifle joints were harvested from 2-year-old control merino wethers from another project, which was being undertaken. The University of Sydney Animal Care and Ethics Committee approved this study under ethics approval A45/6-2011/3/5544 (approved on 1 January 2014) and the ethical permission in this project covered the use of ovine control tissues in other projects such as the present study. Bovine knees were obtained from a local abattoir.

\subsection{Visualisation of Cartilage Surface Components}

Versican, HA and lubricin were visualised in the surface regions of bovine articular cartilage using antibody $12 \mathrm{C} 5$ to the G1 domain of versican, biotinylated HABP was used as described earlier to visualise surface HA deposition [125] and lubricin identified using antibody 3A4.

\subsection{Preparation of Biotinylated Trypsin}

Biotinylated trypsin (bT) was prepared as noted earlier [24] and subjected to a final clean up step on a SBTI Affinity column to ensure a fully active enzyme preparation of high specific activity, this was aliquoted and stored frozen and its activity determined by active site titration $\left(-20^{\circ} \mathrm{C}\right)$.

\subsection{Preparation of Immobilised Hyaluronan}

A column of immobilised HA was prepared as outlined earlier [138,139].

\subsection{Determination of Trypsin Inhibitory Activity}

Aliquots $(50 \mu \mathrm{L})$ of chromatographic fractions were added to individual wells of a flat bottom 96 well microtitre plate followed by assay buffer $\left(50 \mathrm{mM}\right.$ Tris- $\mathrm{HCl} \mathrm{pH} 8.2$ containing $10 \mathrm{mM} \mathrm{CaCl}_{2}$ ). Trypsin $(20-50 \mathrm{ng})$ in assay buffer $(50 \mu \mathrm{L})$ was then added with mixing. The assay was initiated 
by addition of substrate (50 $\mu \mathrm{L}$ of CBZ-Arg-4-nitroanilide in 100\% DMSO) and the plates incubated at $37^{\circ} \mathrm{C}$ for $3-5 \mathrm{~h}$. The plates were then read at $\mathrm{A} 405 \mathrm{~nm}$ using a plate reader. Trypsin inhibitory activity was determined from the drop in A405 nm compared to control wells containing trypsin but no chromatographic fraction.

\subsection{Measurement of the Relative Protease Inhibitory Activity of Bikunin KPI-1, KPI-2 and BPTI}

Trypsin (EC 3.4.21.4, Sigma type XIII from bovine pancreas) treated with N-tosyl-phenylalanine chloromethyl ketone to inactivate any contaminating chymotrypsin activity was assayed with the substrate $N$ - $\alpha$-carbobenzoxy-L-arginine-p-nitroanilide (ZAPNA) [140]. The level of active trypsin was measured using the active site titrant $N$ - $\alpha$-carbobenzoxy-L-arginine p-nitrophenyl ester [141] and used in turn to standardise the KPI-1, KPI-2 and BPTI samples. Chymotrypsin (EC 3.4.21.1, type II from bovine pancreas) was assayed using the substrate Ala-Ala-Val-Ala 4-NA (AAVANA), human neutrophil cathepsin G (EC 3.4.21.20) activity was assayed with N-Succinyl-Ala-Ala-Pro-Phe 4-NA (SAAPPNA). Plasma kallikrein (EC 3.4.21.34) was assayed using D-Val-Leu-Arg 4NA and plasmin (EC 3.4.21.7) was assayed using D-Val-Leu-Lys 4NA. Human leucocyte elastase (HLE) (EC 3.4.21.37) was assayed with $N$ - $\alpha$-succinyl-alanyl-alanyl-valine p-nitroanilide (SAAVNA) [142]. These assays were performed in $50 \mathrm{mM}$ Tris $\mathrm{HCI}, 100 \mathrm{mM} \mathrm{NaCI}, 20 \mathrm{mM} \mathrm{CaCI}, 0.1 \mathrm{mg} / \mathrm{mL}$ of bovine serum albumin (BSA), and $0.02 \%(w / v) \mathrm{NaN}_{3}, \mathrm{pH}$ 8.2. Cathepsin $\mathrm{G}$ (EC 3.4.21.20) was isolated as previously described [136,137], and along with commercial chymotrypsin (EC 3.4.21.1, type II from bovine pancreas) was assayed in $100 \mathrm{mM}$ Tris $\mathrm{HCI}, 100 \mathrm{mM} \mathrm{NaCI}, 10 \mathrm{mM} \mathrm{CaCI}_{2}, 0.1 \mathrm{mg} / \mathrm{mL}$ of BSA, and $0.02 \% \mathrm{NaN}_{3} \mathrm{pH} 7.5$, using $\mathrm{N}$ - $\alpha$-succinyl-alanyl-alanyl-prolylphenylalanine-p-nitroanilide (SAPA) as substrate. Assays were performed with substrate concentrations of $0.2 \mathrm{mM}$ in $4 \%(v / v)$ DMSO at $37^{\circ} \mathrm{C}$ in 96-well microplates in a final reaction volume of $250 \mu \mathrm{L}$. Absorbance values at $405 \mathrm{~nm}$ were recorded, using the absorbance at $690 \mathrm{~nm}$ as a zero reference value.

\subsection{Extraction of Serine Proteinase Inhibitory Proteins from Articular Cartilage}

Finely diced articular cartilage from eight stifle joints of 2-year-old control merino wethers (18 $\mathrm{g}$ wet weight) was extracted with $200 \mathrm{~mL}$ of extraction buffer (6 M Urea $50 \mathrm{mM}$ Tris- $\mathrm{HCl}$ pH 7.2) with constant end-over-end mixing at $4{ }^{\circ} \mathrm{C}$ for $72 \mathrm{~h}$. The tissue residue was then separated by filtration through muslin and the extract clarified by centrifugation $(16,000 \times g$ for $20 \mathrm{~min})$.

\subsection{DEAE Sepharose 4B Anion Exchange Chromatography}

Aliquots of the tissue extract $(50 \mathrm{~mL})$ were applied batch-wise to a $60 \mathrm{~mL}$ bed volume column of DEAE Sepharose at a flow rate of $10 \mathrm{~mL} / \mathrm{h}$ and the column eluted with starting buffer $50 \mathrm{mM}$ Tris- $\mathrm{HCl}$ pH 7.2 $(150 \mathrm{~mL})$. Bound material was eluted with a gradient of $2 \mathrm{M} \mathrm{NaCl}$ in starting buffer as follows, (i) a linear gradient from $0-0.4 \mathrm{M} \mathrm{NaCl}(50 \mathrm{~mL})$, (ii) stepwise change to $2 \mathrm{M} \mathrm{NaCl}(100 \mathrm{~mL})$. Eluant fractions of $10 \mathrm{~mL}$ were collected; aliquots of fractions $(50 \mu \mathrm{L})$ were monitored for relative trypsin inhibitory activity and sulfated GAG content by reaction with 1,9-dimethyl methylene blue. Protein was monitored by the A280 nm of the fractions. SPI containing fractions 14-18 were subsequently pooled and further purified by HA affinity chromatography.

\subsection{HA Affinity Chromatography of the DEAE SPI Pools}

Four SPI pools from DEAE anion exchange were applied to a column of immobilised HA and the column eluted with 3 bed volumes starting buffer ( $50 \mathrm{mM}$ Tris- $\mathrm{HCl} \mathrm{pH} \mathrm{7.2).} \mathrm{Bound} \mathrm{material} \mathrm{was} \mathrm{eluted}$ with $2 \mathrm{M} \mathrm{NaCl}$ in starting buffer. Eluant fractions $(5 \mathrm{~mL})$ were collected at a flow rate of $10 \mathrm{~mL} / \mathrm{h}$. Aliquots $(50 \mu \mathrm{L})$ of fractions were monitored for trypsin inhibitory activity. Bound fractions containing SPI activity were subsequently pooled as shown in Figure 3. 


\subsection{Sephadex G100 Gel Permeation Chromatography of HA Affinity Purified SPI Samples}

A XK16/100 $(1.6 \times 98 \mathrm{~cm})$ column of Sephadex G100 was equilibrated in $50 \mathrm{mM}$ Tris- $\mathrm{HCl} 150 \mathrm{mM}$ $\mathrm{NaCl}$ pH 7.2 and the void volume and total volume of the column determined using Dextran blue and $D$-glucose respectively. Samples of the HA affinity purified SPI pool $(2.0 \mathrm{~mL})$ were applied to the Sephadex G100 column at a flow rate of $8 \mathrm{~mL} / \mathrm{h}$. Eluent fractions $(2 \mathrm{~mL})$ were monitored for protein $(\mathrm{A} 280 \mathrm{~nm})$ and trypsin inhibitory activity. Two SPI pools were subsequently collected by pooling fractions 4-9 (SPI pool 1), and fractions 18-25 (SPI pool 2). After one month of storage at $4{ }^{\circ} \mathrm{C}$ these samples were re-chromatographed.

\subsection{Chymotrypsin Affinity Chromatography}

SPI samples from HA affinity or Sephadex G100 gel permeation chromatography were applied to a column of immobilised chymotrypsin ( $1 \mathrm{~mL}$ bed volume). The column was washed with $1 \mathrm{M} \mathrm{NaCl}$ in $0.5 \mathrm{M}$ sodium acetate, buffer $\mathrm{pH} 4.0$ starting buffer, to remove non-bound material. Bound SPIs were eluted from the column with $3 \mathrm{mM} \mathrm{HCl}, \mathrm{pH} 2.0$, into aliquots of $1 \mathrm{M}$ Tris free base to adjust the $\mathrm{pH}$ of the collected fraction to 7.4.

\subsection{Concanavalin A Lectin Affinity Chromatography of SPI Samples}

SPI samples from HA affinity or Sephadex G100 gel permeation chromatography were applied to a Concanavalin A Sepharose $4 \mathrm{~B}$ column $(3.5 \times 1.5 \mathrm{~cm})$ in $50 \mathrm{mM}$ Tris, $200 \mathrm{mM} \mathrm{NaCl}$ buffer pH 7.2 starting buffer containing $1 \mathrm{mM} \mathrm{CaCl}_{2}, 1 \mathrm{mM} \mathrm{MgCl}_{2}$, and $1 \mathrm{mM} \mathrm{MnCl}_{2}$, at room temperature. The column was washed with 10 bed volumes of starting buffer to remove non-bound material. Bound SPIs were eluted with a linear gradient of $0-0.2 \mathrm{M}$ methyl- $\alpha$-D-glucopyranoside in starting buffer. The ovine AC SPIs eluted at $\sim 0.07 \mathrm{M}$ methyl $\alpha$-D-glucopyranoside.

\subsection{Detection of Active SPIs Using Biotinylated Trypsin and Affinity Blotting}

SPI samples were electrophoresed on Novex 4-20\% SDS-PAGE gradient gels then transferred to $0.45 \mu \mathrm{m}$ nitrocellulose membranes in $12 \mathrm{mM}$ Tris, $96 \mathrm{mM}$ glycine, $\mathrm{pH} 8.3,20 \% v / v$ methanol transfer buffer for $2 \mathrm{~h}$ at $200 \mathrm{~mA}$ [24]. Nitrocellulose membranes were blocked overnight in $20 \mathrm{mM}$ Tris-HCl $500 \mathrm{mM} \mathrm{NaCl} \mathrm{pH} 7.2$ containing $0.1 \% v / v$ Tween 20 (TBS-Tween) then rinsed in TBS-Tween prior to incubation with biotinylated trypsin $(\mathrm{bT}, 0.5 \mu \mathrm{g} / \mathrm{mL})$ in TBS-Tween for $1 \mathrm{~h}$ at room temperature. The membranes were then washed again in TBS-Tween then incubated for $1 \mathrm{~h}$ with avidin-alkaline phosphatase 1/1000 dilution. After a final wash the membranes were incubated in NBT/BCIP substrate in $0.1 \mathrm{M}$ Tris- $\mathrm{HCl} \mathrm{pH} 9.5$ colour development buffer for $20 \mathrm{~min}$.

\subsection{Development of SPI Western Blots with Antibodies to Chondroitin-4 Sulfate Stub Epitope, Bikunin, TSG-6 and $\alpha 1-$ Microglobulin}

SPI samples which had been subjected to electrophoresis on 4-20\% PAG gradient gels in $0.1 \mathrm{M}$ Tris $0.1 \mathrm{M}$ Tricine $\mathrm{pH} 8.4$ and transferred to nitrocellulose membranes in $12 \mathrm{mM}$ Tris, $96 \mathrm{mM}$ glycine, $\mathrm{pH} 8.3,20 \% v / v$ methanol transfer buffer for $2 \mathrm{~h}$ at $200 \mathrm{~mA}$ were blocked overnight in $2 \% w / v \mathrm{BSA}$ in $50 \mathrm{mM}$ Tris- $\mathrm{HCl} \mathrm{pH} 7.2$ containing $0.15 \mathrm{M} \mathrm{NaCl}$ (Tris-saline).

Chondroitinase $\mathrm{ABC} 0.05 \mathrm{U} / \mathrm{mL}$ was added to the 2-B-6 (+) blots and these were incubated at $37^{\circ} \mathrm{C}$ to generate the 2-B-6 (+) stub epitopes from the CS linkage regions during the membrane blocking step. All other blots were blocked overnight in $2 \%$ BSA in Tris-saline at $4{ }^{\circ} \mathrm{C}$. The blocked blots were incubated with a 1/10 dilution of 2-B-6 hybridoma medium, anti-bikunin $(10 \mu \mathrm{g} / \mathrm{mL})$, anti- $\alpha 1$-microglobulin $(5 \mu \mathrm{g} / \mathrm{mL})$ or anti-TSG-6 antibody $(5 \mu \mathrm{g} / \mathrm{mL})$. After incubation overnight at $4{ }^{\circ} \mathrm{C}$ the blots were washed in Tris-saline then anti-rabbit or anti-mouse IgG alkaline phosphatase conjugated secondary antibodies (1/1000 dilution) were added at room temperature for $2 \mathrm{~h}$. After washing again, the blots were incubated with NBT/BCIP in alkaline phosphatase development buffer. Colour development was terminated after $45 \mathrm{~min}$. 


\subsection{Sulfated GAG Analysis}

The sulfated GAG content of eluent fractions was used as an index of their proteoglycan contents. Sulfated GAG was determined by reaction with the metachromatic dye 1,9-dimethyl methylene blue as indicated earlier [143].

\subsection{Cartilage Histological Processing and Confocal Microscopy}

Full thickness bovine cartilage was harvested from the tibial plateau of a 2-year-old steer, fixed in $10 \%$ neutral buffered formalin for $24 \mathrm{~h}$, dehydrated through sequential alcohol washes and xylene and embedded in paraffin. Cartilage sections $(7 \mu \mathrm{m})$ were cut using a microtome, attached to positively charged microscope slides and de-waxed in xylene and then rehydrated, through graded ethanol washes then blocked with normal donkey serum (1:20 dilution) for $30 \mathrm{~min}$ at room temperature. The sections were digested with proteinase $\mathrm{K}$ (Dako) for $20 \mathrm{~min}$ rinsed then incubated with anti-lubricin MAb (3A4; $2 \mu \mathrm{g} / \mathrm{mL})$ anti-versican MAb $(12 \mathrm{C} 5,5 \mu \mathrm{g} / \mathrm{mL})$ or biotinylated HABP $(5 \mu \mathrm{g} / \mathrm{mL})$ in $50 \mathrm{mM}$ Tris- $\mathrm{HCl} \mathrm{pH} \mathrm{7.2} 0.15 \mathrm{M} \mathrm{NaCl}$ overnight at $4{ }^{\circ} \mathrm{C}$. The primary reagents were then detected with Alexa 488 conjugated secondary $\mathrm{Ab}(1 / 1000 \mathrm{diln})$ to mouse IgG or FITC-streptavidin $(10 \mu \mathrm{g} / \mathrm{mL})$ for $8 \mathrm{~h}$, washed in TBS and mounted under coverslips in Vectashield. Propidium iodide was used to stain cell nuclei in the $\mathrm{bHABP}$ and lubricin sections. Fluorescently stained tissue sections were visualised using a Leica TCS SP2 AOBS laser scanning confocal microscope (Leica, Heidelberg, Germany) using a 40× oil immersion objective. The slides were scanned using excitation and emission settings for Alexa 488 (Ex max: 488; Em max: 520) Z-stacks of 8-bit 'optical sections' (512 $\times 512$ pixels) were taken through the full cartilage thickness at $0.4 \mu \mathrm{m}$ increments. 'Maximum Intensity' reconstructions were prepared from the image stacks using Leica Confocal Software (Leica, Heidelberg, Germany).

\subsection{Statistical Analyses}

Protease inhibitory activity data were tested for significance using the Kruskal Wallace equality-of-populations rank test in the first instance. If significance was found $(p<0.05)$, samples were compared using the Wilcoxon rank-sum test. Within each parameter, the Benjamini-Hochberg post-hoc test was used to correct for false positives. All statistical analyses were performed using STATA 15 statistical software (Release 14, StataCorp LP, College Station, TX, USA). Each analysis was based on six replicates and the experiment was repeated on at least two further samples. Data was considered significant when test data vs control data groups displayed $p<0.05$.

\section{Conclusions}

(1) A retrospective analysis of earlier ovine AC and IVD studies combined with data generated in the present study shows that ovine AC and IVD contain SPIs synthesised by their resident cells related to ITI/bikunin which are released from the bikunin precursor protein and display potent inhibitory activity against leucocyte elastase, cathepsin G, trypsin, chymotrypsin, plasmin and kallikrein.

(2) A survey of the literature shows that ITI/bikunin are multifunctional KPI domain proteins with a diverse range of biological properties beyond protease inhibition that are beneficial to tissues in terms of prevention of bacterial, fungal and viral infection, modulation of innate immunity in host-defense and have cell proliferative and anti-tumour properties. The dual function of some KPI domains in protease inhibition and blocking of ion-fluxes in voltage gated ion-channels indicate KPIs may be of therapeutic value in neural disorders. Furthermore, the embedded CS-D motifs in the CS chains of bikunin may equip it with important cell regulatory and neuritogenic properties which need to be explored further.

(3) Studies in other tissues show that HC chain transfer from ITI provides matrix stabilisation in lung tissue, supports oocyte expansion which is essential in fertilisation however in some cases the ITI-HCs may affect HA turnover adversely, deleteriously effecting physiological processes in cystic fibrosis, diabetes, asthma, hyperglycemia and atherosclerosis. 
(4) We have demonstrated components in the cartilage surface that ITI is known to be interactive with in vitro. Such interactions in-situ may result in the localisation of ITI in the surface regions of articular cartilage and would be expected to have important protective roles to play which preserve joint functional properties. Furthermore, by analogy with other tissues, transfer of ITI-HCs by TSG-6 to HA or versican may further stabilise this functionally important surface region of articular cartilage.

(5) Development of biotinylated trypsin is a useful sensitive detection system capable of detecting low ng levels of active KPI domains in bikunin and ITI species demonstrating a further functional dimension to ITI proteoglycan species. This detection system can be used along with conventional immunohistological detection systems and demonstrates the ITI species are biologically active.

Author Contributions: Conceptualisation, J.M. Methodology, J.M, S.M.S.; Formal Analysis, J.M., S.M.S. Investigation, J.M.; Resources, J.M.; Data Curation, J.M., S.M.S.; Writing-Original Draft Preparation, J.M.; Writing-Review \& Editing, J.M., S.M.S.; Visualisation, J.M., S.M.S.; Supervision, J.M. Project Administration, J.M.; Funding Acquisition, J.M.

Funding: National Health and Medical Research Council Project Grant 1004032 funded this study.

Acknowledgments: Prof Bruce Caterson is thanked for the gifts of 2-B-6 hybridoma conditioned medium and $\mathrm{MAb} 3 \mathrm{~A} 4$ to lubricin.

Conflicts of Interest: The author has no financial disclosures or conflicts to report.

\section{Abbreviations}

$\begin{array}{ll}\text { AC } & \text { articular cartilage } \\ \text { ITI } & \text { inter- } \alpha \text {-trypsin inhibitor } \\ \text { Pre- } \alpha \text {-TI } & \text { pre- } \alpha \text {-trypsin inhibitor } \\ \text { SPI } & \text { serine proteinase inhibitor } \\ \text { KPI } & \text { Kunitz protease inhibitor } \\ \text { CS } & \text { Chondroitin sulfate } \\ \text { HC } & \text { heavy chain (ITI) } \\ \text { OA } & \text { osteoarthritis } \\ \text { RA } & \text { rheumatoid arthritis } \\ \text { HA } & \text { hyaluronan } \\ \text { SLPI } & \text { secretory leucocyte proteinase inhibitor } \\ \text { TOM } & \text { Trappin ovine molecule } \\ \text { bT } & \text { biotinylated trypsin } \\ \text { TSG-6 } & \text { Tumour necrosis factor-stimulated gene-6 } \\ \text { GAG } & \text { glycosaminoglycan } \\ \text { KPI } & \text { Kunitz protease inhibitor } \\ \text { KS } & \text { Kaposi sarcoma } \\ \text { UTS } & \text { urinary trypsin inhibitor } \\ \text { BPTI } & \text { basic pancreatic trypsin inhibitor } \\ \text { IVD } & \text { intervertebral disc } \\ \text { ChD } & \text { chondrodystrophoid } \\ \text { Non-ChD } & \text { non-chondrodystrophoid } \\ & \end{array}$

\section{References}

1. Steinbuch, M.; Loeb, J. Isolation of an alpha2-globulin from human plasma. Nature 1961, 192, 1196. [CrossRef] [PubMed]

2. Hochstrasser, K.; Albrecht, G.; Schonberger, O.L.; Wachter, E. Kunitz-type proteinase inhibitors derived by limited proteolysis of the inter-alpha-trypsin inhibitor, VII. Characterization of the bovine inhibitor as double-headed trypsin-elastase inhibitor. Hoppe Seylers Z. Physiol. Chem. 1983, 364, 1689-1696. [CrossRef] [PubMed] 
3. Hochstrasser, K.; Wachter, E.; Albrecht, G.J.; Reisinger, P. Kunitz-type proteinase inhibitors derived by limited proteolysis of the inter-alpha-trypsin inhibitor, $X$. The amino-acid sequences of the trypsin-released inhibitors from horse and pig inter-alpha-trypsin inhibitors. Biol. Chem. Hoppe Seyler 1985, 366, 473-478. [CrossRef]

4. Wachter, E.; Hochstrasser, K. Kunitz-type proteinase inhibitors derived by limited proteolysis of the inter-alpha-trypsin inhibitor, III. Sequence of the two Kunitz-type domains inside the native inter-alpha-trypsin inhibitor, its biological aspects and also of its cleavage products. Hoppe Seylers Z. Physiol. Chem. 1979, 360, 1305-1311. [CrossRef] [PubMed]

5. Salier, J.P. Inter-alpha-trypsin inhibitor: Emergence of a family within the Kunitz-type protease inhibitor superfamily. Trends Biochem. Sci. 1990, 15, 435-439. [CrossRef]

6. Nishimura, H.; Kakizaki, I.; Muta, T.; Sasaki, N.; Pu, P.X.; Yamashita, T.; Nagasawa, S. cDNA and deduced amino acid sequence of human PK-120, a plasma kallikrein-sensitive glycoprotein. FEBS Lett. 1995, 357, 207-211. [CrossRef]

7. Saguchi, K.; Tobe, T.; Hashimoto, K.; Sano, Y.; Nakano, Y.; Miura, N.H.; Tomita, M. Cloning and characterization of cDNA for inter-alpha-trypsin inhibitor family heavy chain-related protein (IHRP), a novel human plasma glycoprotein. J. Biochem. 1995, 117, 14-18. [CrossRef] [PubMed]

8. Hochstrasser, K.; Schonberger, O.L.; Rossmanith, I.; Wachter, E. Kunitz-type proteinase inhibitors derived by limited proteolysis of the inter-alpha-trypsin inhibitor, V. Attachments of carbohydrates in the human urinary trypsin inhibitor isolated by affinity chromatography. Hoppe Seylers Z. Physiol. Chem. 1981, 362, 1357-1362. [CrossRef] [PubMed]

9. Chi, L.; Wolff, J.J.; Laremore, T.N.; Restaino, O.F.; Xie, J.; Schiraldi, C.; Toida, T.; Amster, I.J.; Linhardt, R.J. Structural analysis of bikunin glycosaminoglycan. J. Am. Chem. Soc. 2008, 130, 2617-2625. [CrossRef] [PubMed]

10. Lord, M.S.; Day, A.J.; Youssef, P.; Zhuo, L.; Watanabe, H.; Caterson, B.; Whitelock, J.M. Sulfation of the bikunin chondroitin sulfate chain determines heavy chain.hyaluronan complex formation. J. Biol. Chem. 2013, 288, 22930-22941. [CrossRef] [PubMed]

11. Ly, M.; Leach, F.E., 3rd; Laremore, T.N.; Toida, T.; Amster, I.J.; Linhardt, R.J. The proteoglycan bikunin has a defined sequence. Nat. Chem. Biol. 2011, 7, 827-833. [CrossRef] [PubMed]

12. Zhuo, L.; Salustri, A.; Kimata, K. A physiological function of serum proteoglycan bikunin: The chondroitin sulfate moiety plays a central role. Glycoconj. J. 2002, 19, 241-247. [CrossRef] [PubMed]

13. Zhuo, L.; Hascall, V.C.; Kimata, K. Inter-alpha-trypsin inhibitor, a covalent protein-glycosaminoglycanprotein complex. J. Biol. Chem. 2004, 279, 38079-38082. [CrossRef] [PubMed]

14. Hamm, A.; Veeck, J.; Bektas, N.; Wild, P.J.; Hartmann, A.; Heindrichs, U.; Kristiansen, G.; Werbowetski-Ogilvie, T.; Del Maestro, R.; Knuechel, R.; et al. Frequent expression loss of Inter-alpha-trypsin inhibitor heavy chain (ITIH) genes in multiple human solid tumors: A systematic expression analysis. BMC Cancer 2008, 8, 25. [CrossRef] [PubMed]

15. Huth, S.; Heise, R.; Vetter-Kauczok, C.S.; Skazik, C.; Marquardt, Y.; Czaja, K.; Knuchel, R.; Merk, H.F.; Dahl, E.; Baron, J.M. Inter-alpha-trypsin inhibitor heavy chain 5 (ITIH5) is overexpressed in inflammatory skin diseases and affects epidermal morphology in constitutive knockout mice and murine 3D skin models. Exp. Dermatol. 2015, 24, 663-668. [CrossRef] [PubMed]

16. Yoshihara, Y.; Plaas, A.; Osborn, B.; Margulis, A.; Nelson, F.; Stewart, M.; Rugg, M.S.; Milner, C.M.; Day, A.J.; Nemoto, K.; et al. Superficial zone chondrocytes in normal and osteoarthritic human articular cartilages synthesize novel truncated forms of inter-alpha-trypsin inhibitor heavy chains which are attached to a chondroitin sulfate proteoglycan other than bikunin. Osteoarthr. Cartil. 2008, 16, 1343-1355. [CrossRef] [PubMed]

17. Lamkin, E.; Cheng, G.; Calabro, A.; Hascall, V.C.; Joo, E.J.; Li, L.; Linhardt, R.J.; Lauer, M.E. Heavy chain transfer by tumor necrosis factor-stimulated gene 6 to the bikunin proteoglycan. J. Biol. Chem. 2015, 290, 5156-5166. [CrossRef]

18. Rodgers, K.J.; Melrose, J.; Ghosh, P. Purification and characterisation of 6 and $58 \mathrm{kDa}$ forms of the endogenous serine proteinase inhibitory proteins of ovine articular cartilage. Biol. Chem. 1996, 377, 837-845.

19. Melrose, J.; Smith, S.; Ghosh, P. Synthesis of a Kunitz-type serine proteinase inhibitory protein that shares homology with bovine pancreatic trypsin inhibitor by ovine intervertebral disc cells in serum-free alginate bead culture. J. Spinal Disord. Tech. 2002, 15, 164-171. [CrossRef] 
20. Rodgers, K.J.; Melrose, J.; Ghosh, P. Biotin-labeled potato chymotrypsin inhibitor-1: A useful probe for the detection and quantitation of chymotrypsin-like serine proteinases on western blots and its application in the detection of a serine proteinase synthesised by articular chondrocytes. Anal. Biochem. 1995, 227, 129-134. [CrossRef]

21. Rodgers, K.J.; Melrose, J.; Ghosh, P. Biotinylated trypsin and its application as a sensitive, versatile probe for the detection and characterisation of an ovine chondrocyte serine proteinase inhibitor using Western blotting. Electrophoresis 1996, 17, 213-218. [CrossRef]

22. Rasp, G.; Hochstrasser, K.; Wachter, E.; Reisinger, P.W. The amino-acid sequence of the trypsin-released inhibitor from sheep inter-alpha-trypsin inhibitor. Biol. Chem. Hoppe Seyler 1987, 368, 727-731. [CrossRef] [PubMed]

23. Melrose, J.; Rodgers, K. Preparation and use of biotinylated probes for the detection and characterisation of serine proteinases and serine proteinase inhibitory proteins. In A Laboratory Guide to Biotin Labelling in Biomolecule Analysis; Meier, T., Fahrenholz, F., Eds.; Birkhauser Publishin: Basel, Switzerland, 1996.

24. Melrose, J.; Rodgers, K.; Ghosh, P. The preparation and use of biotinylated trypsin in western blotting for the detection of trypsin inhibitory proteins. Anal. Biochem. 1994, 222, 34-43. [CrossRef] [PubMed]

25. Andrews, J.L.; Melrose, J.; Ghosh, P. A comparative study of the low-molecular mass serine proteinase inhibitors of human connective tissues. Biol. Chem. Hoppe Seyler 1992, 373, 111-118. [CrossRef] [PubMed]

26. Melrose, J.; Ghosh, P. Development of an avidin-biotin competitive inhibition assay and validation of its use for the quantitation of human intervertebral disc serine proteinase inhibitory proteins. Anal. Biochem. 1992, 204, 372-382. [CrossRef]

27. Melrose, J.; Ghosh, P.; Taylor, T.K.; Andrews, J.L. The serine proteinase inhibitory proteins of the human intervertebral disc: Their isolation, characterization and variation with ageing and degeneration. Matrix 1992, 12, 456-470. [CrossRef]

28. Melrose, J.; Shen, B.; Ghosh, P. Affinity and Western blotting reveal homologies between ovine intervertebral disc serine proteinase inhibitory proteins and bovine pancreatic trypsin inhibitor. Proteomics 2001, 1, 1529-1533. [CrossRef]

29. Melrose, J.; Smith, S.; Rodgers, K.; Little, C.; Burkhardt, D.; Ghosh, P. Immunolocalisation of BPTI-like serine proteinase inhibitory proteins in mast cells, chondrocytes and intervertebral disc fibrochondrocytes of ovine and bovine connective tissues. An immunohistochemical and biochemical study. Histochem. Cell Biol. 2000, 114, 137-146.

30. Melrose, J.; Taylor, T.K.; Ghosh, P. Variation in intervertebral disc serine proteinase inhibitory proteins with ageing in a chondrodystrophoid (beagle) and a non-chondrodystrophoid (greyhound) canine breed. Gerontology 1996, 42, 322-329. [CrossRef]

31. Melrose, J.; Taylor, T.K.; Ghosh, P. The serine proteinase inhibitory proteins of the chondrodystrophoid (beagle) and non-chondrodystrophoid (greyhound) canine intervertebral disc. Electrophoresis 1997, 18, 1059-1063. [CrossRef]

32. Fries, E.; Blom, A.M. Bikuni-Not just a plasma proteinase inhibitor. Int. J. Biochem. Cell Biol. 2000, 32, 125-137. [CrossRef]

33. Kanayama, S.; Yamada, Y.; Onogi, A.; Shigetomi, H.; Ueda, S.; Tsuji, Y.; Haruta, S.; Kawaguchi, R.; Yoshida, S.; Sakata, M.; et al. Molecular structure and function analysis of bikunin on down-regulation of tumor necrosis factor-alpha expression in activated neutrophils. Cytokine 2008, 42, 191-197. [CrossRef] [PubMed]

34. Kapoor, S. Bikunin and its emerging role in the modulation of tumor invasion and metastasis. J. Surg. Res. 2013, 183, 982. [CrossRef] [PubMed]

35. Kobayashi, H.; Suzuki, M.; Hirashima, Y.; Terao, T. The protease inhibitor bikunin, a novel anti-metastatic agent. Biol. Chem. 2003, 384, 749-754. [CrossRef] [PubMed]

36. Kobayashi, H.; Suzuki, M.; Tanaka, Y.; Kanayama, N.; Terao, T. A Kunitz-type protease inhibitor, bikunin, inhibits ovarian cancer cell invasion by blocking the calcium-dependent transforming growth factor-beta 1 signaling cascade. J. Biol. Chem. 2003, 278, 7790-7799. [CrossRef] [PubMed]

37. Matsuzaki, H.; Kobayashi, H.; Yagyu, T.; Wakahara, K.; Kondo, T.; Kurita, N.; Sekino, H.; Inagaki, K.; Suzuki, M.; Kanayama, N.; et al. Bikunin inhibits lipopolysaccharide-induced tumor necrosis factor alpha induction in macrophages. Clin. Diagn. Lab. Immunol. 2004, 11, 1140-1147. [CrossRef] 
38. Roberts, S.; Evans, H.; Menage, J.; Urban, J.P.; Bayliss, M.T.; Eisenstein, S.M.; Rugg, M.S.; Milner, C.M.; Griffin, S.; Day, A.J. TNFalpha-stimulated gene product (TSG-6) and its binding protein, IalphaI, in the human intervertebral disc: New molecules for the disc. Eur. Spine J. 2005, 14, 36-42. [CrossRef]

39. Briggs, D.C.; Birchenough, H.L.; Ali, T.; Rugg, M.S.; Waltho, J.P.; Ievoli, E.; Jowitt, T.A.; Enghild, J.J.; Richter, R.P.; Salustri, A.; et al. Metal Ion-dependent Heavy Chain Transfer Activity of TSG-6 Mediates Assembly of the Cumulus-Oocyte Matrix. J. Biol. Chem. 2015, 290, 28708-28723. [CrossRef] [PubMed]

40. Richards, J.S. Ovulation: New factors that prepare the oocyte for fertilization. Mol. Cell. Endocrinol. 2005, 234, 75-79. [CrossRef]

41. Melrose, J.; Shu, C.; Whitelock, J.M.; Lord, M.S. The cartilage extracellular matrix as a transient developmental scaffold for growth plate maturation. Matrix Biol. 2016, 52-54, 363-383. [CrossRef]

42. Sallenave, J.M. Antimicrobial activity of antiproteinases. Biochem. Soc. Trans. 2002, 30, 111-115. [CrossRef] [PubMed]

43. Sallenave, J.M. Secretory leukocyte protease inhibitor and elafin/trappin-2: Versatile mucosal antimicrobials and regulators of immunity. Am. J. Respir. Cell Mol. Biol. 2010, 42, 635-643. [CrossRef] [PubMed]

44. Quabius, E.S.; Gorogh, T.; Fischer, G.S.; Hoffmann, A.S.; Gebhard, M.; Evert, M.; Beule, A.; Maune, S.; Knecht, R.; Ovari, A.; et al. The antileukoprotease secretory leukocyte protease inhibitor (SLPI) and its role in the prevention of HPV-infections in head and neck squamous cell carcinoma. Cancer Lett. 2015, 357, 339-345. [CrossRef] [PubMed]

45. Quabius, E.S.; Moller, P.; Haag, J.; Pfannenschmidt, S.; Hedderich, J.; Gorogh, T.; Rocken, C.; Hoffmann, M. The role of the antileukoprotease SLPI in smoking-induced human papillomavirus-independent head and neck squamous cell carcinomas. Int. J. Cancer 2014, 134, 1323-1334. [CrossRef] [PubMed]

46. Wahl, S.M.; McNeely, T.B.; Janoff, E.N.; Shugars, D.; Worley, P.; Tucker, C.; Orenstein, J.M. Secretory leukocyte protease inhibitor (SLPI) in mucosal fluids inhibits HIV-I. Oral Dis. 1997, 3 (Suppl. 1), S64-S69. [CrossRef] [PubMed]

47. McNeely, T.B.; Dealy, M.; Dripps, D.J.; Orenstein, J.M.; Eisenberg, S.P.; Wahl, S.M. Secretory leukocyte protease inhibitor: A human saliva protein exhibiting anti-human immunodeficiency virus 1 activity in vitro. J. Clin. Investig. 1995, 96, 456-464. [CrossRef] [PubMed]

48. Kobayashi, H.; Yoshida, R.; Kanada, Y.; Fukuda, Y.; Yagyu, T.; Inagaki, K.; Kondo, T.; Kurita, N.; Suzuki, M.; Kanayama, N.; et al. Suppression of lipopolysaccharide-induced cytokine production of gingival fibroblasts by a soybean, Kunitz trypsin inhibitor. J. Periodontal. Res. 2005, 40, 461-468. [CrossRef]

49. Wakahara, K.; Kobayashi, H.; Yagyu, T.; Matsuzaki, H.; Kondo, T.; Kurita, N.; Sekino, H.; Inagaki, K.; Suzuki, M.; Kanayama, N.; et al. Bikunin suppresses lipopolysaccharide-induced lethality through down-regulation of tumor necrosis factor- alpha and interleukin-1 beta in macrophages. J. Infect. Dis. 2005, 191, 930-938. [CrossRef]

50. Majchrzak-Gorecka, M.; Majewski, P.; Grygier, B.; Murzyn, K.; Cichy, J. Secretory leukocyte protease inhibitor (SLPI), a multifunctional protein in the host defense response. Cytokine Growth Factor Rev. 2016, 28, 79-93. [CrossRef]

51. Scott, A.; Weldon, S.; Taggart, C.C. SLPI and elafin: Multifunctional antiproteases of the WFDC family. Biochem. Soc. Trans. 2011, 39, 1437-1440. [CrossRef]

52. Chen, X.; Rivard, L.; Naqvi, S.; Nakada, S.; Padbury, J.F.; Sanchez-Esteban, J.; Stopa, E.G.; Lim, Y.P.; Stonestreet, B.S. Expression and localization of Inter-alpha Inhibitors in rodent brain. Neuroscience 2016, 324, 69-81. [CrossRef] [PubMed]

53. Garcia-Fernandez, R.; Peigneur, S.; Pons, T.; Alvarez, C.; Gonzalez, L.; Chavez, M.A.; Tytgat, J. The Kunitz-Type Protein ShPI-1 Inhibits Serine Proteases and Voltage-Gated Potassium Channels. Toxins (Basel) 2016, 8, 110. [CrossRef] [PubMed]

54. Mahdi, F.; Rehemtulla, A.; Van Nostrand, W.E.; Bajaj, S.P.; Schmaier, A.H. Protease nexin-2/Amyloid beta-protein precursor regulates factor VIIa and the factor VIIa-tissue factor complex. Thromb. Res. 2000, 99, 267-276. [CrossRef]

55. Peigneur, S.; Billen, B.; Derua, R.; Waelkens, E.; Debaveye, S.; Beress, L.; Tytgat, J. A bifunctional sea anemone peptide with Kunitz type protease and potassium channel inhibiting properties. Biochem. Pharm. 2011, 82, 81-90. [CrossRef] [PubMed] 
56. Schweitz, H.; Bruhn, T.; Guillemare, E.; Moinier, D.; Lancelin, J.M.; Beress, L.; Lazdunski, M. Kalicludines and kaliseptine. Two different classes of sea anemone toxins for voltage sensitive $\mathrm{K}+$ channels. J. Biol. Chem. 1995, 270, 25121-25126. [CrossRef] [PubMed]

57. Schweitz, H.; Heurteaux, C.; Bois, P.; Moinier, D.; Romey, G.; Lazdunski, M. Calcicludine, a venom peptide of the Kunitz-type protease inhibitor family, is a potent blocker of high-threshold $\mathrm{Ca}^{2+}$ channels with a high affinity for L-type channels in cerebellar granule neurons. Proc. Natl. Acad. Sci. USA 1994, 91, 878-882. [CrossRef] [PubMed]

58. Yang, W.; Feng, J.; Wang, B.; Cao, Z.; Li, W.; Wu, Y.; Chen, Z. BF9, the first functionally characterized snake toxin peptide with Kunitz-type protease and potassium channel inhibiting properties. J. Biochem. Mol. Toxicol. 2014, 28, 76-83. [CrossRef]

59. Jacoby, A.S.; Melrose, J.; Robinson, B.G.; Hyland, V.J.; Ghosh, P. Secretory leucocyte proteinase inhibitor is produced by human articular cartilage chondrocytes and intervertebral disc fibrochondrocytes. Eur. J. Biochem. 1993, 218, 951-957. [CrossRef]

60. Ohlsson, S.; Tufvesson, B.; Polling, A.; Ohlsson, K. Distribution of the secretory leucocyte proteinase inhibitor in human articular cartilage. Biol. Chem. 1997, 378, 1055-1058. [CrossRef]

61. Brown, T.I.; Mistry, R.; Collie, D.D.; Tate, S.; Sallenave, J.M. Trappin ovine molecule (TOM), the ovine ortholog of elafin, is an acute phase reactant in the lung. Physiol. Genom. 2004, 19, 11-21. [CrossRef]

62. Brown, T.I.; Mistry, R.; Gray, R.; Imrie, M.; Collie, D.D.; Sallenave, J.M. Characterization of the ovine ortholog of secretory leukoprotease inhibitor. Mamm. Genome 2005, 16, 621-630. [CrossRef]

63. Baranger, K.; Zani, M.L.; Labas, V.; Dallet-Choisy, S.; Moreau, T. Secretory leukocyte protease inhibitor (SLPI) is, like its homologue trappin-2 (pre-elafin), a transglutaminase substrate. PLoS ONE 2011, 6, e20976. [CrossRef] [PubMed]

64. Albrecht, G.J.; Hochstrasser, K.; Schonberger, O.L. Kunitz-type proteinase inhibitors derived by limited proteolysis of the inter-alpha-trypsin inhibitor, IX. Isolation and characterization of the inhibitory parts of inter-alpha-trypsin inhibitors from several mammalian sera. Hoppe Seylers Z. Physiol. Chem. 1983, 364, 1697-1702. [CrossRef] [PubMed]

65. Gebhard, W.; Schreitmuller, T.; Vetr, H.; Wachter, E.; Hochstrasser, K. Complementary DNA and deduced amino acid sequences of procine alpha 1-microglobulin and bikunin. FEBS Lett. 1990, 269, 32-36. [CrossRef]

66. Glant, T.T.; Kamath, R.V.; Bardos, T.; Gal, I.; Szanto, S.; Murad, Y.M.; Sandy, J.D.; Mort, J.S.; Roughley, P.J.; Mikecz, K. Cartilage-specific constitutive expression of TSG-6 protein (product of tumor necrosis factor alpha-stimulated gene 6) provides a chondroprotective, but not antiinflammatory, effect in antigen-induced arthritis. Arthritis Rheum. 2002, 46, 2207-2218. [CrossRef] [PubMed]

67. Fouladi-Nashta, A.A.; Raheem, K.A.; Marei, W.F.; Ghafari, F.; Hartshorne, G.M. Regulation and roles of the hyaluronan system in mammalian reproduction. Reproduction 2017, 153, R43-R58. [CrossRef] [PubMed]

68. Hamasuna, R.; Kataoka, H.; Meng, J.Y.; Itoh, H.; Moriyama, T.; Wakisaka, S.; Koono, M. Reduced expression of hepatocyte growth factor activator inhibitor type-2/placental bikunin (HAI-2/PB) in human glioblastomas: Implication for anti-invasive role of HAI-2/PB in glioblastoma cells. Int. J. Cancer 2001, 93, 339-345. [CrossRef] [PubMed]

69. Suzuki, M.; Kobayashi, H.; Fujie, M.; Nishida, T.; Takigawa, M.; Kanayama, N.; Terao, T. Kunitz-type protease inhibitor bikunin disrupts phorbol ester-induced oligomerization of CD44 variant isoforms containing epitope v9 and subsequently suppresses expression of urokinase-type plasminogen activator in human chondrosarcoma cells. J. Biol. Chem. 2002, 277, 8022-8032. [CrossRef] [PubMed]

70. Griffiths, S.J.; Adams, D.J.; Talbot, S.J. Ribonuclease inhibits Kaposi's sarcoma. Nature 1997, $390,568$. [CrossRef]

71. Griffiths, S.J.; Bramley, T.A.; Menzies, G.S.; Adams, D.J. Co-purification of a ribonuclease and human chorionic gonadotrophin beta-core protein from human urine and displacement of 125I-human luteinizing hormone from Candida albicans binding sites by ribonucleases. Mol. Cell. Endocrinol. 1997, 134, 69-76. [CrossRef]

72. Lee-Huang, S.; Huang, P.L.; Sun, Y.; Kung, H.F.; Blithe, D.L.; Chen, H.C. Lysozyme and RNases as anti-HIV components in beta-core preparations of human chorionic gonadotropin. Proc. Natl. Acad. Sci. USA 1999, 96, 2678-2681. [CrossRef] [PubMed] 
73. Lunardi-Iskandar, Y.; Bryant, J.L.; Blattner, W.A.; Hung, C.L.; Flamand, L.; Gill, P.; Hermans, P.; Birken, S.; Gallo, R.C. Effects of a urinary factor from women in early pregnancy on HIV-1, SIV and associated disease. Nat. Med. 1998, 4, 428-434. [CrossRef] [PubMed]

74. Samaniego, F.; Bryant, J.L.; Liu, N.; Karp, J.E.; Sabichi, A.L.; Thierry, A.; Lunardi-Iskandar, Y.; Gallo, R.C. Induction of programmed cell death in Kaposi's sarcoma cells by preparations of human chorionic gonadotropin. J. Natl. Cancer Inst. 1999, 91, 135-143. [CrossRef] [PubMed]

75. Malatos, S.; Neubert, H.; Kicman, A.T.; Iles, R.K. Identification of placental transforming growth factor-beta and bikunin metabolites as contaminants of pharmaceutical human chorionic gonadotrophin preparations by proteomic techniques. Mol. Cell. Proteom. 2005, 4, 984-992. [CrossRef] [PubMed]

76. Matuska, B.; Comhair, S.; Farver, C.; Chmiel, J.; Midura, R.J.; Bonfield, T.; Lauer, M.E. Pathological Hyaluronan Matrices in Cystic Fibrosis Airways and Secretions. Am. J. Respir. Cell Mol. Biol. 2016, 55, 576-585. [CrossRef] [PubMed]

77. Lorentzen, K.A.; Chai, S.; Chen, H.; Danielsen, C.C.; Simonsen, U.; Wogensen, L. Mechanisms involved in extracellular matrix remodeling and arterial stiffness induced by hyaluronan accumulation. Atherosclerosis 2016, 244, 195-203. [CrossRef] [PubMed]

78. Lauer, M.E.; Majors, A.K.; Comhair, S.; Ruple, L.M.; Matuska, B.; Subramanian, A.; Farver, C.; Dworski, R.; Grandon, D.; Laskowski, D.; et al. Hyaluronan and Its Heavy Chain Modification in Asthma Severity and Experimental Asthma Exacerbation. J. Biol. Chem. 2015, 290, 23124-23134. [CrossRef]

79. Bogdani, M.; Johnson, P.Y.; Potter-Perigo, S.; Nagy, N.; Day, A.J.; Bollyky, P.L.; Wight, T.N. Hyaluronan and hyaluronan-binding proteins accumulate in both human type 1 diabetic islets and lymphoid tissues and associate with inflammatory cells in insulitis. Diabetes 2014, 63, 2727-2743. [CrossRef]

80. Bourguignon, J.; Borghi, H.; Sesboue, R.; Diarra-Mehrpour, M.; Bernaudin, J.F.; Metayer, J.; Martin, J.P.; Thiberville, L. Immunohistochemical distribution of inter-alpha-trypsin inhibitor chains in normal and malignant human lung tissue. J. Histochem. Cytochem. 1999, 47, 1625-1632. [CrossRef]

81. Yoshida, E.; Maruyama, M.; Sugiki, M.; Mihara, H. Immunohistochemical demonstration of bikunin, a light chain of inter-alpha-trypsin inhibitor, in human brain tumors. Inflammation 1994, 18, 589-596. [CrossRef]

82. Eguchi, Y.; Inoue, M.; Iida, S.; Matsuoka, K.; Noda, S. Heparan sulfate (HS)/heparan sulfate proteoglycan (HSPG) and bikunin are up-regulated during calcium oxalate nephrolithiasis in rat kidney. Kurume Med. J. 2002, 49, 99-107. [CrossRef] [PubMed]

83. Evan, A.P.; Bledsoe, S.; Worcester, E.M.; Coe, F.L.; Lingeman, J.E.; Bergsland, K.J. Renal inter-alpha-trypsin inhibitor heavy chain 3 increases in calcium oxalate stone-forming patients. Kidney Int. 2007, 72, 1503-1511. [CrossRef] [PubMed]

84. Kanayama, N.; Maehara, K.; She, L.; Belayet, H.M.; Khatun, S.; Tokunaga, N.; Terao, T. Urinary trypsin inhibitor suppresses vascular smooth muscle contraction by inhibition of Ca2+influx. Biochim. Biophys. Acta 1998, 1381, 139-146. [CrossRef]

85. Kanayama, N.; Halim, A.; Maehara, K.; Kajiwara, Y.; Fujie, M.; Terao, T. Kunitz-type trypsin inhibitor prevents LPS-induced increase of cytosolic free $\mathrm{Ca}^{2+}$ in human neutrophils and HUVEC cells. Biochem. Biophys. Res. Commun. 1995, 207, 324-330. [CrossRef] [PubMed]

86. Flo, M.; Margenat, M.; Pellizza, L.; Grana, M.; Duran, R.; Baez, A.; Salceda, E.; Soto, E.; Alvarez, B.; Fernandez, C. Functional diversity of secreted cestode Kunitz proteins: Inhibition of serine peptidases and blockade of cation channels. PLoS Pathog. 2017, 13, e1006169. [CrossRef]

87. Pangalos, M.N.; Shioi, J.; Efthimiopoulos, S.; Wu, A.; Robakis, N.K. Characterization of appican, the chondroitin sulfate proteoglycan form of the Alzheimer amyloid precursor protein. Neurodegeneration 1996, 5, 445-451. [CrossRef] [PubMed]

88. Chen, Z.; Luo, F.; Feng, J.; Yang, W.; Zeng, D.; Zhao, R.; Cao, Z.; Liu, M.; Li, W.; Jiang, L.; et al. Genomic and structural characterization of Kunitz-type peptide LmKTT-1a highlights diversity and evolution of scorpion potassium channel toxins. PLoS ONE 2013, 8, e60201. [CrossRef]

89. Hennies, H.C. All is balanced: Inter-alpha-trypsin inhibitors as unseen extracellular matrix proteins in epidermal morphology and differentiation. Exp. Dermatol. 2015, 24, 661-662. [CrossRef]

90. Edqvist, P.H.; Fagerberg, L.; Hallstrom, B.M.; Danielsson, A.; Edlund, K.; Uhlen, M.; Ponten, F. Expression of human skin-specific genes defined by transcriptomics and antibody-based profiling. J. Histochem. Cytochem. 2015, 63, 129-141. [CrossRef] 
91. Fagerberg, L.; Hallstrom, B.M.; Oksvold, P.; Kampf, C.; Djureinovic, D.; Odeberg, J.; Habuka, M.; Tahmasebpoor, S.; Danielsson, A.; Edlund, K.; et al. Analysis of the human tissue-specific expression by genome-wide integration of transcriptomics and antibody-based proteomics. Mol. Cell. Proteom. 2014, 13, 397-406. [CrossRef]

92. Lindskog, C. The potential clinical impact of the tissue-based map of the human proteome. Expert Rev. Proteom. 2015, 12, 213-215. [CrossRef] [PubMed]

93. Petryszak, R.; Burdett, T.; Fiorelli, B.; Fonseca, N.A.; Gonzalez-Porta, M.; Hastings, E.; Huber, W.; Jupp, S.; Keays, M.; Kryvych, N.; et al. Expression Atlas update-A database of gene and transcript expression from microarray- and sequencing-based functional genomics experiments. Nucleic Acids Res. 2014, 42, D926-D932. [CrossRef] [PubMed]

94. Ponten, F.; Jirstrom, K.; Uhlen, M. The Human Protein Atlas-A tool for pathology. J. Pathol. 2008, 216, 387-393. [CrossRef]

95. Uhlen, M.; Fagerberg, L.; Hallstrom, B.M.; Lindskog, C.; Oksvold, P.; Mardinoglu, A.; Sivertsson, A.; Kampf, C.; Sjostedt, E.; Asplund, A.; et al. Proteomics. Tissue-based map of the human proteome. Science 2015, 347, 1260419. [CrossRef] [PubMed]

96. Kloten, V.; Rose, M.; Kaspar, S.; von Stillfried, S.; Knuchel, R.; Dahl, E. Epigenetic inactivation of the novel candidate tumor suppressor gene ITIH5 in colon cancer predicts unfavorable overall survival in the CpG island methylator phenotype. Epigenetics 2014, 9, 1290-1301. [CrossRef]

97. Zhang, S.; Zhu, Y.T.; Chen, S.Y.; He, H.; Tseng, S.C. Constitutive expression of pentraxin 3 (PTX3) protein by human amniotic membrane cells leads to formation of the heavy chain (HC)-hyaluronan (HA)-PTX3 complex. J. Biol. Chem. 2014, 289, 13531-13542. [CrossRef]

98. Torihashi, S.; Ho, M.; Kawakubo, Y.; Komatsu, K.; Nagai, M.; Hirayama, Y.; Kawabata, Y.; Takenaka-Ninagawa, N.; Wanachewin, O.; Zhuo, L.; et al. Acute and temporal expression of tumor necrosis factor (TNF)-alpha-stimulated gene 6 product, TSG6, in mesenchymal stem cells creates microenvironments required for their successful transplantation into muscle tissue. J. Biol. Chem. 2015, 290, 22771-22781. [CrossRef]

99. Itoh, H.; Ide, H.; Ishikawa, N.; Nawa, Y. Mast cell protease inhibitor, trypstatin, is a fragment of inter-alphatrypsin inhibitor light chain. J. Biol. Chem. 1994, 269, 3818-3822.

100. Dobbertin, A.; Rhodes, K.E.; Garwood, J.; Properzi, F.; Heck, N.; Rogers, J.H.; Fawcett, J.W.; Faissner, A. Regulation of RPTPbeta/phosphacan expression and glycosaminoglycan epitopes in injured brain and cytokine-treated glia. Mol. Cell. Neurosci. 2003, 24, 951-971. [CrossRef]

101. Faissner, A.; Heck, N.; Dobbertin, A.; Garwood, J. DSD-1-Proteoglycan/Phosphacan and receptor protein tyrosine phosphatase-beta isoforms during development and regeneration of neural tissues. Adv. Exp. Med. Biol. 2006, 557, 25-53.

102. Garwood, J.; Rigato, F.; Heck, N.; Faissner, A. Tenascin glycoproteins and the complementary ligand DSD-1-PG/ phosphacan-structuring the neural extracellular matrix during development and repair. Restor. Neurol. Neurosci. 2001, 19, 51-64. [PubMed]

103. Garwood, J.; Schnadelbach, O.; Clement, A.; Schutte, K.; Bach, A.; Faissner, A. DSD-1-proteoglycan is the mouse homolog of phosphacan and displays opposing effects on neurite outgrowth dependent on neuronal lineage. J. Neurosci. 1999, 19, 3888-3899. [CrossRef] [PubMed]

104. Ito, Y.; Hikino, M.; Yajima, Y.; Mikami, T.; Sirko, S.; von Holst, A.; Faissner, A.; Fukui, S.; Sugahara, K. Structural characterization of the epitopes of the monoclonal antibodies 473HD, CS-56, and MO-225 specific for chondroitin sulfate D-type using the oligosaccharide library. Glycobiology 2005, 15, 593-603. [CrossRef] [PubMed]

105. Margolis, R.U.; Margolis, R.K. Chondroitin sulfate proteoglycans as mediators of axon growth and pathfinding. Cell Tissue Res. 1997, 290, 343-348. [CrossRef] [PubMed]

106. Hikino, M.; Mikami, T.; Faissner, A.; Vilela-Silva, A.C.; Pavao, M.S.; Sugahara, K. Oversulfated dermatan sulfate exhibits neurite outgrowth-promoting activity toward embryonic mouse hippocampal neurons: Implications of dermatan sulfate in neuritogenesis in the brain. J. Biol. Chem. 2003, 278, 43744-43754. [CrossRef] [PubMed]

107. Takano, M.; Mori, Y.; Shiraki, H.; Horie, M.; Okamoto, H.; Narahara, M.; Miyake, M.; Shikimi, T. Detection of bikunin mRNA in limited portions of rat brain. Life Sci. 1999, 65, 757-762. [CrossRef] 
108. Garwood, J.; Heck, N.; Reichardt, F.; Faissner, A. Phosphacan short isoform, a novel non-proteoglycan variant of phosphacan/receptor protein tyrosine phosphatase-beta, interacts with neuronal receptors and promotes neurite outgrowth. J. Biol. Chem. 2003, 278, 24164-24173. [CrossRef]

109. Yoshida, K.; Suzuki, Y.; Yamamoto, K.; Sinohara, H. Guinea pig alpha 1-microglobulin/bikunin: CDNA sequencing, tissue expression and expression during acute phase. Comp. Biochem. Physiol. B Biochem. Mol. Biol. 1999, 122, 165-172. [CrossRef]

110. Pangalos, M.N.; Shioi, J.; Robakis, N.K. Expression of the chondroitin sulfate proteoglycans of amyloid precursor (appican) and amyloid precursor-like protein 2. J. Neurochem. 1995, 65, 762-769. [CrossRef]

111. Shioi, J.; Pangalos, M.N.; Ripellino, J.A.; Vassilacopoulou, D.; Mytilineou, C.; Margolis, R.U.; Robakis, N.K. The Alzheimer amyloid precursor proteoglycan (appican) is present in brain and is produced by astrocytes but not by neurons in primary neural cultures. J. Biol. Chem. 1995, 270, 11839-11844. [CrossRef]

112. Tsuchida, K.; Shioi, J.; Yamada, S.; Boghosian, G.; Wu, A.; Cai, H.; Sugahara, K.; Robakis, N.K. Appican, the proteoglycan form of the amyloid precursor protein, contains chondroitin sulfate $\mathrm{E}$ in the repeating disaccharide region and 4-O-sulfated galactose in the linkage region. J. Biol. Chem. 2001, 276, 37155-37160. [CrossRef] [PubMed]

113. Umehara, Y.; Yamada, S.; Nishimura, S.; Shioi, J.; Robakis, N.K.; Sugahara, K. Chondroitin sulfate of appican, the proteoglycan form of amyloid precursor protein, produced by $\mathrm{C} 6$ glioma cells interacts with heparin-binding neuroregulatory factors. FEBS Lett. 2004, 557, 233-238. [CrossRef]

114. Wu, A.; Pangalos, M.N.; Efthimiopoulos, S.; Shioi, J.; Robakis, N.K. Appican expression induces morphological changes in $\mathrm{C} 6$ glioma cells and promotes adhesion of neural cells to the extracellular matrix. J. Neurosci. 1997, 17, 4987-4993. [CrossRef]

115. Kawamura, D.; Funakoshi, T.; Mizumoto, S.; Sugahara, K.; Iwasaki, N. Sulfation patterns of exogenous chondroitin sulfate affect chondrogenic differentiation of ATDC5 cells. J. Orthop. Sci. 2014, 19, 1028-1035. [CrossRef] [PubMed]

116. Suzuki, M.; Kobayashi, H.; Tanaka, Y.; Hirashima, Y.; Kanayama, N.; Takei, Y.; Saga, Y.; Itoh, H.; Terao, T. Bikunin target genes in ovarian cancer cells identified by microarray analysis. J. Biol. Chem. 2003, 278, 14640-14646. [CrossRef] [PubMed]

117. Bonnevie, E.D.; Galesso, D.; Secchieri, C.; Cohen, I.; Bonassar, L.J. Elastoviscous Transitions of Articular Cartilage Reveal a Mechanism of Synergy between Lubricin and Hyaluronic Acid. PLoS ONE 2015, 10, e0143415. [CrossRef] [PubMed]

118. Elsaid, K.; Chichester, C.O.; Jay, G.D. Cathepsin B and neutrophil elastase degrade lubricin and increase friction in excised murine joints. In Proceedings of the 51st Annual Meeting of the Orthopaedic Research Society, Washington, DC, USA, 20-23 February 2005. Post No. 0924.

119. Elsaid, K.A.; Jay, G.D.; Chichester, C.O. Reduced expression and proteolytic susceptibility of lubricin/superficial zone protein may explain early elevation in the coefficient of friction in the joints of rats with antigen-induced arthritis. Arthritis Rheum. 2007, 56, 108-116. [CrossRef] [PubMed]

120. Jay, G.D.; Waller, K.A. The biology of lubricin: Near frictionless joint motion. Matrix Biol. 2014, 39, 17-24. [CrossRef] [PubMed]

121. Kuroda, K.; Fujimoto, N.; Tajima, S. Abnormal accumulation of inter-alpha-trypsin inhibitor and hyaluronic acid in lichen sclerosus. J. Cutan. Pathol. 2005, 32, 137-140. [CrossRef] [PubMed]

122. Martin, D.C.; Atmuri, V.; Hemming, R.J.; Farley, J.; Mort, J.S.; Byers, S.; Hombach-Klonisch, S.; Csoka, A.B.; Stern, R.; Triggs-Raine, B.L. A mouse model of human mucopolysaccharidosis IX exhibits osteoarthritis. Hum. Mol. Genet. 2008, 17, 1904-1915. [CrossRef]

123. Melrose, J.; Tammi, M.; Smith, S. Visualisation of hyaluronan and hyaluronan-binding proteins within ovine vertebral cartilages using biotinylated aggrecan G1-link complex and biotinylated hyaluronan oligosaccharides. Histochem. Cell Biol. 2002, 117, 327-333. [CrossRef]

124. Kao, W.W.; Coulson-Thomas, V.J. Cell Therapy of Corneal Diseases. Cornea 2016, 35 (Suppl. 1), S9-S19. [CrossRef] [PubMed]

125. Shay, E.; He, H.; Sakurai, S.; Tseng, S.C. Inhibition of angiogenesis by HC.HA, a complex of hyaluronan and the heavy chain of inter-alpha-inhibitor, purified from human amniotic membrane. Investig. Ophthalmol. Vis. Sci. 2011, 52, 2669-2678. [CrossRef] [PubMed] 
126. Alquraini, A.; Garguilo, S.; D'Souza, G.; Zhang, L.X.; Schmidt, T.A.; Jay, G.D.; Elsaid, K.A. The interaction of lubricin/proteoglycan 4 (PRG4) with toll-like receptors 2 and 4: An anti-inflammatory role of PRG4 in synovial fluid. Arthritis Res. 2015, 17, 353. [CrossRef] [PubMed]

127. Das, N.; Schmidt, T.A.; Krawetz, R.J.; Dufour, A. Proteoglycan 4: From Mere Lubricant to Regulator of Tissue Homeostasis and Inflammation: Does proteoglycan 4 have the ability to buffer the inflammatory response? Bioessays 2019, 41, e1800166. [CrossRef]

128. Bottazzi, B.; Doni, A.; Garlanda, C.; Mantovani, A. An integrated view of humoral innate immunity: Pentraxins as a paradigm. Annu. Rev. Immunol. 2010, 28, 157-183. [CrossRef] [PubMed]

129. Inforzato, A.; Jaillon, S.; Moalli, F.; Barbati, E.; Bonavita, E.; Bottazzi, B.; Mantovani, A.; Garlanda, C. The long pentraxin PTX3 at the crossroads between innate immunity and tissue remodelling. Tissue Antigens 2011, 77, 271-282. [CrossRef] [PubMed]

130. Petrey, A.C.; de la Motte, C.A. Hyaluronan, a crucial regulator of inflammation. Front. Immunol. $2014,5,101$. [CrossRef]

131. Flowers, S.A.; Zieba, A.; Ornros, J.; Jin, C.; Rolfson, O.; Bjorkman, L.I.; Eisler, T.; Kalamajski, S.; Kamali-Moghaddam, M.; Karlsson, N.G. Lubricin binds cartilage proteins, cartilage oligomeric matrix protein, fibronectin and collagen II at the cartilage surface. Sci. Rep. 2017, 7, 13149. [CrossRef]

132. Majd, S.E.; Kuijer, R.; Kowitsch, A.; Groth, T.; Schmidt, T.A.; Sharma, P.K. Both hyaluronan and collagen type II keep proteoglycan 4 (lubricin) at the cartilage surface in a condition that provides low friction during boundary lubrication. Langmuir 2014, 30, 14566-14572. [CrossRef]

133. Lee, Y.; Choi, J.; Hwang, N.S. Regulation of lubricin for functional cartilage tissue regeneration: A review. Biomater. Res. 2018, 22, 9. [CrossRef] [PubMed]

134. Luo, S.; Shi, Q.; Chen, J.; Wang, H.; Wu, W.; Zha, Z. Expression and Significance of MMPs in Synovial Fluid, Serum and PBMC Culture Supernatant Stimulated by LPS in Osteoarthritis Patients With or Without Diabetes. Exp. Clin. Endocrinol. Diabetes 2017. [CrossRef] [PubMed]

135. Roberts, S.; Evans, H.; Wright, K.; van Niekerk, L.; Caterson, B.; Richardson, J.B.; Kumar, K.H.; Kuiper, J.H. ADAMTS-4 activity in synovial fluid as a biomarker of inflammation and effusion. Osteoarthr. Cartil. 2015, 23, 1622-1626. [CrossRef] [PubMed]

136. Andrews, J.L.; Ghosh, P.; Lentini, A.; Ternai, B. The interaction of pentosan polysulfate (SP54) with human neutrophil elastase and connective tissue matrix components. Chem. Biol. Interact. 1983, 47, 157-173. [CrossRef]

137. Baugh, R.J.; Travis, J. Human leukocyte granule elastase: Rapid isolation and characterization. Biochemistry 1976, 15, 836-841. [CrossRef] [PubMed]

138. Melrose, J. Cartilage and smooth muscle cell proteoglycans detected by affinity blotting using biotinylated hyaluronan. Methods Mol. Biol. 2001, 171, 53-66. [PubMed]

139. Melrose, J.; Numata, Y.; Ghosh, P. Biotinylated hyaluronan: A versatile and highly sensitive probe capable of detecting nanogram levels of hyaluronan binding proteins (hyaladherins) on electroblots by a novel affinity detection procedure. Electrophoresis 1996, 17, 205-212. [CrossRef] [PubMed]

140. Somorin, O.; Tokura, S.; Nishi, N.; Noguchi, J. The action of trypsin on synthetic chromogenic arginine substrates. J. Biochem. 1979, 85, 157-162. [CrossRef]

141. Ascenzi, P.; Menegatti, E.; Guarneri, M.; Amiconi, G. Active-site titration of serine proteinases acting selectively on cationic substrates by $\mathrm{N}$-alpha-carbobenzoxy-L-arginine p-nitrophenyl ester and $\mathrm{N}$-alpha-carbobenzoxy-L-lysine p-nitrophenyl ester; determination of active enzyme concentration. Biochim. Biophys. Acta 1987, 915, 421-425. [CrossRef]

142. Wenzel, H.R.; Tschesche, H. Cleavage of peptide-4-nitroanilide substrates with varying chain length by human leukocyte elastase. Hoppe Seylers Z. Physiol. Chem. 1981, 362, 829-831.

143. Farndale, R.W.; Sayers, C.A.; Barrett, A.J. A direct spectrophotometric microassay for sulfated glycosaminoglycans in cartilage cultures. Connect. Tissue Res. 1982, 9, 247-248. [CrossRef] [PubMed]

(C) 2019 by the authors. Licensee MDPI, Basel, Switzerland. This article is an open access article distributed under the terms and conditions of the Creative Commons Attribution (CC BY) license (http:/ / creativecommons.org/licenses/by/4.0/). 